Article

\title{
Evaluation of Shale Source Rocks and Clay Mineral Diagenesis in the Permian Basin, USA: Inferences on Basin Thermal Maturity and Source Rock Potential
}

\author{
Hunter Green ${ }^{1, *}$, Branimir Šegvić ${ }^{1}$ (D) Giovanni Zanoni ${ }^{1}$, Silvia Omodeo-Salé ${ }^{2}$ and \\ Thierry Adatte ${ }^{3}$ \\ 1 Department of Geosciences, Texas Tech University, 1200 Memorial Circle, Lubbock, TX 79409, USA; \\ Branimir.Segvic@ttu.edu (B.Š.); Giovanni.Zanoni@ttu.edu (G.Z.) \\ 2 Department of Earth Sciences, University of Geneva, Rue des Maraîchers 13, 1205 Geneva, Switzerland; \\ Silvia.OmodeoSale@unige.ch \\ 3 Institut des sciences de la Terre, Université de Lausanne, Bâtiment GEOPOLIS, 1015 Lausanne, Switzerland; \\ thierry.adatte@unil.ch \\ * Correspondence: h.green@ttu.edu
}

Received: 4 September 2020; Accepted: 19 September 2020; Published: 23 September 2020

\begin{abstract}
The use of mineral diagenetic indices and organic matter maturity is useful for reconstructing the evolution of sedimentary basins and critical assessments for potential source rocks for petroleum exploration. In this study, the relationship of clay mineral diagenesis and organic matter thermal indices (Rock-Eval Tmax) and calculated vitrinite reflectance $\left(\% R_{0}\right)$ were used to constrain the maximum burial depths and temperatures of three distinct intervals within the northern Permian Basin, USA. X-ray diffraction of clay fractions $(<2 \mu \mathrm{m})$ consists of illite, chlorite, and illite-smectite intermediates. Primary clay mineral diagenetic changes progressively increase in ordering from R0 to R1 I-S between 2359.5 and $2485.9 \mathrm{~m}$ and the appearance of chlorite at $2338.7 \mathrm{~m}$. Rock-Eval pyrolysis data show 0 to $14 \mathrm{wt} \%$ TOC, HI values of 40 to $520 \mathrm{mgHC} / \mathrm{g}$ TOC, and S2 values of 0 to 62 $\mathrm{mg} \mathrm{HC} / \mathrm{g}$, with primarily type II kerogen with calculated $\% \mathrm{R}_{\mathrm{o}}$ within the early to peak oil maturation window. Evaluation of the potential for oil generation is relatively good throughout the Tonya 401 and JP Chilton wells. Organic maturation indices $\left(\operatorname{Tmax}, \% R_{\mathrm{o}}\right.$ ) and peak burial temperatures correlate well with clay mineral diagenesis (R0-R1 I-S), indicating that maximum burial depths and temperatures were between 2.5 and $4 \mathrm{~km}$ and $<100{ }^{\circ} \mathrm{C}$ and $140^{\circ} \mathrm{C}$, respectively. Additionally, the use of clay mineral-derived temperatures provides insight into discrepancies between several calculated $\% \mathrm{R}_{\mathrm{o}}$ equations and thus should be further investigated for use in the Permian Basin. Accordingly, these findings show that clay mineral diagenesis, combined with other paleothermal proxies, can considerably improve the understanding of the complex burial history of the Permian Basin in the context of the evolution of the southern margin of Laurentia.
\end{abstract}

Keywords: shale diagenesis; thermal maturity; clay minerals; source rocks; Permian Basin

\section{Introduction}

Fine-grained organic-rich sedimentary rocks when subjected to sufficient heating and pressure are capable of becoming petroleum source rocks and/or important reservoirs for unconventional hydrocarbon production [1-3]. Unconventional reservoir production potential is highly dependent on a variety of physical and chemical properties that are controlled by depositional environment and post-depositional diagenetic history [4-9]. Post-depositional thermal histories are likely the biggest factor in transforming both inorganic components (i.e., minerals), which in turn affect rocks' physical nature [10-13], and organic matter by maturation into hydrocarbon [14-18]. Therefore, an 
understanding of both the mineral and organic matter histories during burial and subsequent thermal progression are key to comprehending the potential for unconventional hydrocarbon exploration, and provide important insight to the geologic evolution of sedimentary basins [11,19-21].

Thermal history reconstruction, especially within a hydrocarbon producing basin, is typically assessed by means of Rock-Eval pyrolysis, which produces data related to the quality and quantity of organic matter. The temperature index (Tmax) obtained from Rock-Eval pyrolysis is widely used as a maturity index due to its correlation with the increase of organic matter maturation [14]. However, Tmax must be cautiously considered as a thermal maturity indicator due to factors, such as (i) small amount of organic matter in the sample, (ii) deterioration of organic matter, and (iii) varying types of organic matter at the maximum of their thermal maturity [22-26]. Vitrinite reflectance $\left(\% R_{\mathrm{o}}\right)$ observations through organic petrography, especially in shale, has become the standard evaluation tool for thermal maturity [27-31]. Vitrinite reflectance is useful due to its systematic increase with increased organic matter maturation and burial depths as well as preferred arrangements in structure due to overlying stress from load pressure [27]. However, $\% R_{o}$ interpretations can be time consuming, relying heavily on the experience of the organic petrographer [29]. Calculated vitrinite reflectance conversion values using Rock-Eval pyrolysis data have been theoretically developed for several source rocks within a number of sedimentary basins $[23,30]$ and can be further adjusted with the incorporation of mineral maturation indices [31].

Alterations of clay mineral assemblages, in particular mixed-layer illite-smectite (I-S) ratios and illite or chlorite crystallinity indices, have also been used to determine the maximum burial depths and interpret thermal evolution in sedimentary basins [11-14,20,21,24,32-36]. The smectite to illite ratio in mixed-layer I-S as well as the ordering of mixed-layers are both variables that are susceptible to the temperature increase with depth and are controlled by the illitization process $[12,37,38]$. These diagenetic changes coincide with temperatures at which organic matter starts to generate liquid hydrocarbons $[11,33,37]$; therefore, understanding the mineralogy and presence of I-S mixed-layered phases can be used as a geothermal indicator of potential source rocks and maximum burial temperatures.

The ability to constrain different maturation techniques at times in which only some data are available or when techniques must be modified (calculated $\% R_{o}$ by Rock-Eval pyrolysis $[30,31]$ ) can prove helpful during the development of unconventional shale reservoirs. The Wolfcamp, and to a lesser extent Barnett, unconventional shale plays within the Midland Basin, a small sub-basin of the Permian Basin, are some of the largest producing shale plays in the world [39]. The development of these plays has led to sizeable amounts of research employing various analytical approaches, such as vitrinite reflectance, palynofacies, total organic carbon (TOC) variability, and Rock-Eval pyrolysis, to evaluate the types of organic matter presence and source rock potential (e.g., [28,40-42]). However, the assessment of clay mineral presence, particularly the mixed-layered I-S phases, and diagenesis has been severely generalized in most mineralogical studies and limited to just few reports on the specifics of clay mineral phases $[43,44]$. Due to potential variability of maturation indices dealing with organic materials, the importance of using inorganic maturation indices as an indicator for thermal history becomes essential to better understand maturation processes for the construction of diagenetic models [19-21,23-25]. This study aimed to (1) determine the mineralogy and diagenesis of clay minerals within the northern Midland Basin, (2) determine the relationship between clay mineral thermal indices and organic matter maturation parameters (Tmax and calculated $\% R_{o}$ ), and (3) extrapolate northern Midland Basin data throughout the basin to better refine thermal history regimes.

\section{Geological Background}

\subsection{Paleogeography and Tectonics}

The area of Permian Basin (Figure 1) was located along the southern margin of Laurentia where a series of sedimentary basins developed throughout the Paleozoic $[45,46]$. The ancestral Tobosa Basin, a 
low-relief marine depression $[47,48]$, covered much of southern craton during the Early Paleozoic. The basin was fairly inactive tectonically until the Late Mississippian when weak crustal extension and subsidence began to deepen the basin [49]. During the Pennsylvanian, the collision of Laurentia and Gondwana led to the development of the Marathon-Ouachita fold-thrust belt, creating the modern foredeep Permian Basin [50-52]. Deformation continued along high-angle fault structures through the Pennsylvanian, establishing three distinct sub-basins, the Midland (the focus of this study), Delaware, and Val Verde Basins $[49,50,53]$. The Midland Basin actively started to assemble during the Middle Pennsylvanian, with several pulses of subsidence through the Early Triassic $[45,50,54]$. Following this period, the Midland Basin would remain virtually inactive throughout the Mesozoic, until Laramide tectonics lifted and tilted the basin asymmetrically from west to east to its present-day depths [49].

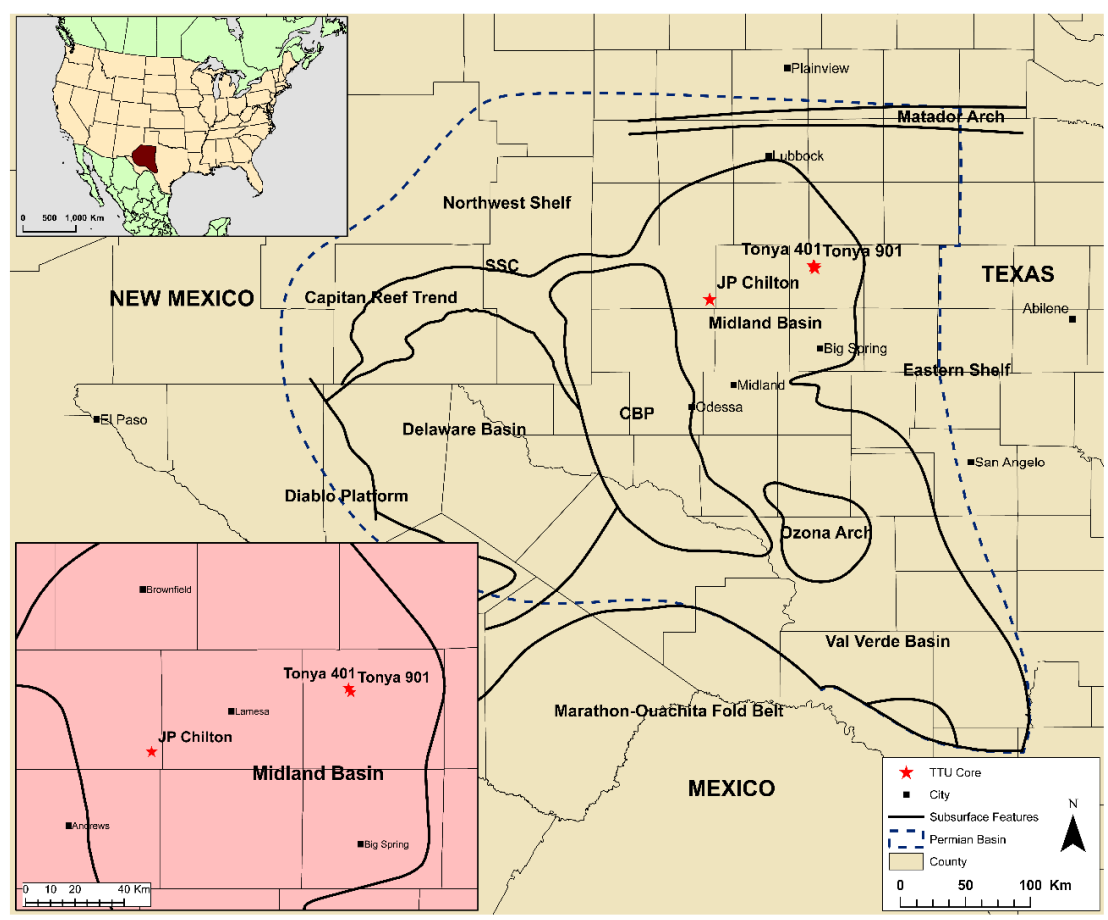

Figure 1. Geographic location of the Greater Permian Basin region with associated subsurface basins. The cored samples are denoted by the red stars within the northern Midland Basin.

\subsection{Deposition and Stratigraphy}

Passive margin secessions dominated the ancestral Tobosa Basin during the Early Paleozoic, alternating between thick accumulations of shelf carbonates, basinal shales, and nearshore clastics [54]. Late Mississippian transgressions in the region deposited fine-grained, dark gray and brown, organic-rich sediments of the Barnett formation (Figure 2; [55]). This section is unconformably overlain by Pennsylvanian age Atoka and Bend formations and marks the fall of relative sea-level ending the Kaskaskia megasequence [54,55]. At the beginning of the Pennsylvanian, regional structures started to shift, creating uplifts within and around the basin, altering sedimentary regimens and constructing environments conducive to clastic deposition along the northwest margin and progressively more sediment starved towards the center and southern margins [56,57]. As time progressed through the Pennsylvanian, tectonic activity, rapid subsidence, and intense glacio-eustatic sea-level deviations controlled the widespread deposition of cyclothems, creating sequences of Strawn and Canyon formation shelf carbonates with time-equivalent detrital limestones and basinal clastic turbidity deposits (Figure 2, [54,57-61]). Upper Pennsylvanian Wolfcamp D/Cline formation is commonly gray to black organic-rich marine shales with increased carbonated detritus near the margins of the basin (Figure 2) [57]. In the Early Permian, continued subsidence accompanied by deltaic progradation from 
the north and east supplied clastic sediment from the Ouachita fold-thrust belt [58] though incised valleys and troughs along the Eastern Shelf, giving rise to the Wolfcamp formation (Figure 2) [61-63]. Sediment conduits captured carbonate detritus and debris from exposed platform shelves, creating a series of mass flows, turbidite, and basin-floor submarine facies fanning throughout the basin [61,64-66]. As sea water receded, the basin began to fill with additional clastics and prograding carbonate margins until the Late Permian when thick accumulations of evaporite deposits covered the area [54,57]. Previously, several subsidence curves were constructed [50,67], depicting steady rates throughout the Paleozoic until the Middle to Late Pennsylvanian, in which rates dramatically increased during the Permian. These previous models suggest that Wolfcampian-aged rocks within the eastern Midland Basin (Figure 3) reached depths of approximately $2-2.5 \mathrm{~km}$ at the end of the Permian. Subtle uplifts and erosional events during the Mesozoic allowed the exhumation and non-deposition of sediments [54]. Finally, during the Cretaceous, marine sediments covered the entire Midland Basin, once again burying Pennsylvanian and Permian source rocks within the Western Interior seaway, until uplift from Laramide events positioned them to current depths [54,67-69].

\begin{tabular}{|c|c|c|c|}
\hline System & Epoch/Series/Stage & Midland Basin & General Stratigraphy \\
\hline \multirow{9}{*}{10} & \multirow{7}{*}{ Leonardian } & Upper Leonard & \multirow{2}{*}{ 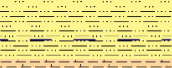 } \\
\hline & & Upper Spraberry & \\
\hline & & Middle Spraberry & 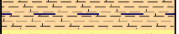 \\
\hline & & Lower Spraberry & 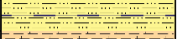 \\
\hline & & Middle Leonard & \\
\hline & & Dean & \\
\hline & & Lower Leonard (Wolfcamp A) & 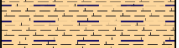 \\
\hline & \multirow{2}{*}{ Wolfcampian } & Wolfcamp B & 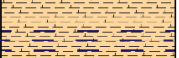 \\
\hline & & Wolfcamp C & $1=$ \\
\hline \multirow{4}{*}{$\begin{array}{l}\frac{c}{\pi} \\
\frac{\pi}{\pi} \\
\frac{\pi}{2} \\
\frac{\pi}{\lambda} \\
\frac{1}{c} \\
\frac{c}{d} \\
\frac{1}{2}\end{array}$} & Vrigilian & Wolfcamp D/Cline & $=$ \\
\hline & Missourian & Canyon & 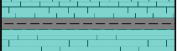 \\
\hline & Desmoinesian & Strawn & 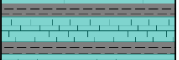 \\
\hline & Atokan & Atoka/Bend & 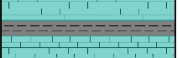 \\
\hline \multirow{4}{*}{ Mississippian } & Chesterian & Barnett & \\
\hline & Meramecian & \multirow{3}{*}{ Mississippian } & \begin{tabular}{|llll}
1 & 1 \\
\end{tabular} \\
\hline & Osagean & & $\begin{array}{llll}1 & 1 & 1 & 1 \\
1 & 1 & 1 & 1\end{array}$ \\
\hline & Kiderhookian & & $\begin{array}{lll}1 & 1,1,1,1,1 \\
& 1,1,1,1\end{array}$ \\
\hline Devonian & Famennian & Woodford & $=--$ \\
\hline
\end{tabular}

Figure 2. Stratigraphic nomenclature used within the Midland Basin. Core intervals are noted by the black columns. General lithologies and stratigraphy are modified after Ewing (2016) [54] and Hamlin and Baumgardner, (2012) [65]. Ash bed intervals are modified after Leslie et al. (2019) [70].

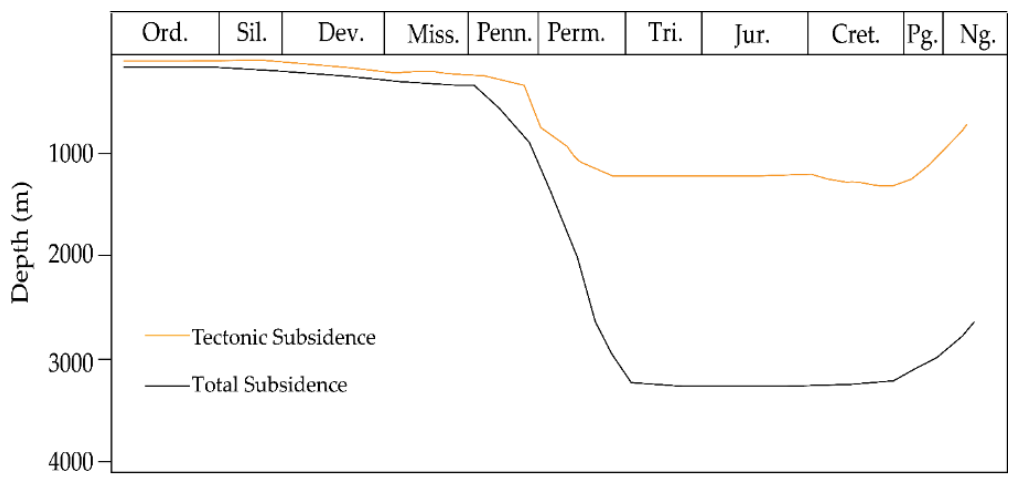

Figure 3. Subsidence curve for the eastern part of the Midland Basin after Yang and Dorobek, 1995 [54], Ewing, 1993 [67], and Heij and Elmore, 2020 [71]. 


\section{Materials and Methods}

\subsection{Sample Materials}

Samples listed in Table 1, were selected from three cores located within the Midland Basin from depths ranging between 2322 and $3400 \mathrm{~m}$ (7620-11,200 ft.) with a focus on three primarily fine-grained siliciclastics units of Mississippian, Pennsylvanian, and Permian age. Tonya 401 and Tonya 901 cores are located in eastern Midland Basin, with the JP Chilton core located in western Midland Basin (Figure 4). Cores were described using petrological techniques and nomenclature schemes developed by Lazar et al., 2015 [72]. Representative samples were then chosen for X-ray diffraction (XRD), clay mineral modeling, and Rock-Eval pyrolysis analyses.

Table 1. List of analyzed drill core samples from multiple wells within the Midland Basin.

\begin{tabular}{|c|c|c|c|c|c|c|}
\hline Sample & Lease & County & Location & Depth m (ft) & Lithofacies & Applied Methods \\
\hline T901-7620 & Tonya 901 & Borden & NE MB & $2323(7620)$ & Black siliceous shale & XRD, CL, CM, REP \\
\hline T901-7627 & Tonya 901 & Borden & NE MB & $2324(7627)$ & Brown calcareous shale & OP, XRD, CL, CM \\
\hline T901-7641 & Tonya 901 & Borden & NE MB & $2329(7641)$ & Brown calcareous shale & OP, XRD, REP \\
\hline T901-7649 & Tonya 901 & Borden & NE MB & $2330(7649)$ & Brown calcareous shale & OP, REP \\
\hline T901-7650 & Tonya 901 & Borden & NE MB & $2330(7650)$ & Brown dolomite & OP, XRD \\
\hline T901-7657 & Tonya 901 & Borden & NE MB & $2333(7657)$ & Brown calcareous shale & OP, XRD, CL, CM \\
\hline T901-7669 & Tonya 901 & Borden & NE MB & 2337 (7669) & Brown dolomitic shale & $\mathrm{OP}, \mathrm{XRD}, \mathrm{CL}, \mathrm{CM}$ \\
\hline T901-7673 & Tonya 901 & Borden & NE MB & $2339(7673)$ & Black siliceous shale & $\mathrm{XRD}, \mathrm{CL}, \mathrm{CM}, \mathrm{REP}$ \\
\hline T901-7690 & Tonya 901 & Borden & NE MB & $2343(7690)$ & Black siliceous shale & $\mathrm{OP}, \mathrm{XRD}$ \\
\hline T901-7700 & Tonya 901 & Borden & NE MB & $2133(7000)$ & Brown calcareous shale & $\mathrm{OP}, \mathrm{XRD}$ \\
\hline T901-7718 & Tonya 901 & Borden & NE MB & $2352(7718)$ & Black siliceous shale & OP, XRD, CL, CM, REP \\
\hline T901-7741 & Tonya 901 & Borden & NE MB & $2359(7741)$ & Black shale & $\mathrm{XRD}, \mathrm{CL}, \mathrm{CM}$ \\
\hline T901-8197 & Tonya 901 & Borden & NE MB & 2498 (8197) & Black shale & OP, XRD, CL, CM \\
\hline T901-8217 & Tonya 901 & Borden & NE MB & 2505 (8217) & Black shale & OP, XRD, CL, CM, REP \\
\hline T901-8236 & Tonya 901 & Borden & NE MB & $2510(8236)$ & Black shale & XRD, REP \\
\hline T901-8252 & Tonya 901 & Borden & NE MB & $2515(8252)$ & Black shale & $\mathrm{CL}, \mathrm{CM}$ \\
\hline T901-8256 & Tonya 901 & Borden & NE MB & $2516(8256)$ & Black shale & $\mathrm{CL}, \mathrm{CM}$ \\
\hline T901-8275 & Tonya 901 & Borden & NE MB & $2522(8275)$ & Brown limestone & OP, XRD, REP \\
\hline T901-8289 & Tonya 901 & Borden & NE MB & $2526(8289)$ & Brown dolomitic shale & OP, XRD, REP \\
\hline T901-8306 & Tonya 901 & Borden & NE MB & $2532(8306)$ & Brown siltstone & OP, XRD, REP \\
\hline T901-8239 & Tonya 901 & Borden & NE MB & 2511 (8239) & Black shale & XRD \\
\hline T901-8357 & Tonya 901 & Borden & NE MB & 2547 (8357) & Black shale & OP, XRD, REP \\
\hline T401-9004 & Tonya 401 & Borden & NE MB & $2744(9004)$ & Dark grey mudstone & $\mathrm{OP}, \mathrm{CL}, \mathrm{CM}, \mathrm{REP}$ \\
\hline T401-9029 & Tonya 401 & Borden & NE MB & $2752(2029)$ & Grey mudstone & XRD \\
\hline T401-9030 & Tonya 401 & Borden & NE MB & 2752 (9030)] & Black-grey shale & OP, XRD \\
\hline T401-9031 & Tonya 401 & Borden & NE MB & $2752(9031)$ & Black shale & OP, XRD, REP \\
\hline T401-9032 & Tonya 401 & Borden & NE MB & $2752(9032)$ & Black-grey shale & XRD \\
\hline T401-9033 & Tonya 401 & Borden & NE MB & $2752(9033)$ & Black shale & $\mathrm{OP}$ \\
\hline T401-9034 & Tonya 401 & Borden & NE MB & $2753(9034)$ & Black-grey shale & OP, XRD, REP \\
\hline T401-9035 & Tonya 401 & Borden & NE MB & 2753 (9035) & Black limestone & XRD \\
\hline JP11091 & JP Chilton \#1 & Gaines & NW MB & 3381 (11091) & Black shale & CL, CM, REP \\
\hline JP11107 & JP Chilton \#1 & Gaines & NW MB & 3385 (11107) & Black shale & CL, CM, REP \\
\hline JP11118 & JP Chilton \#1 & Gaines & NW MB & 3389 (11118) & Black shale & CL, CM, REP \\
\hline JP11135 & JP Chilton \#1 & Gaines & NW MB & 3394 (11135) & Black shale & CL, CM, REP \\
\hline
\end{tabular}

Abbreviations: NE-Northeast; NW—Northwest; MB—Midland Basin; OP—Optical petrography; XRD—whole rock x-ray diffraction; CL-clay fraction $(<2 \mu \mathrm{m})$ X-ray diffraction; CM-clay mineral modeling; REP-Rock-Eval pyrolysis. 


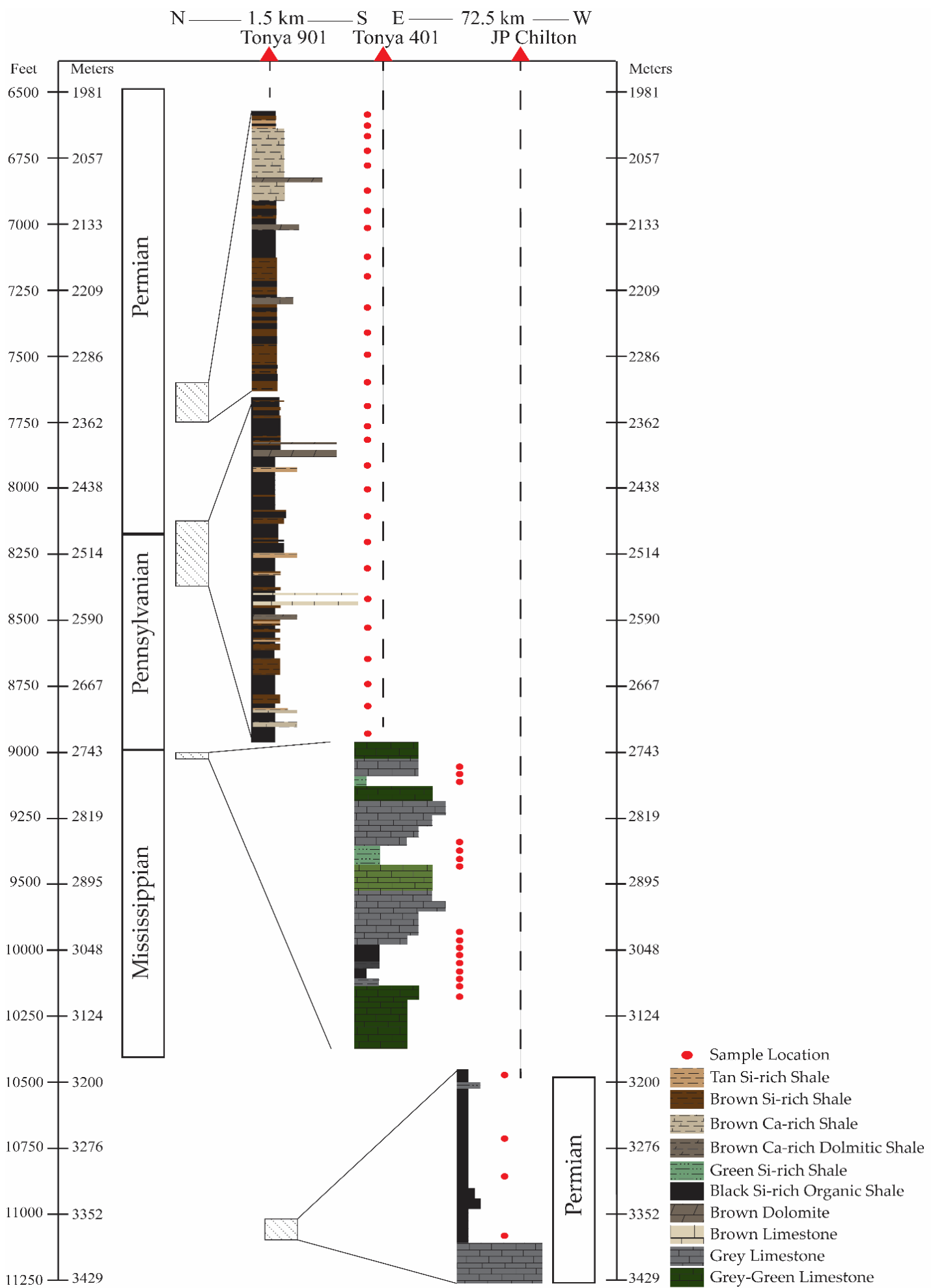

Figure 4. Stratigraphic column of the Tonya 401, Tonya 901, and JP Chilton cores used for this study. Core intervals are exaggerated to depict grain size and lithologies associated to the sampling interval. Vertical scale 1in. $=76.2 \mathrm{~m}$ (250 ft.). Refer to Figure 1 for well locations within the northern Midland Basin.

\subsection{X-Ray Diffraction}

Sample preparation for XRD analyses initially included material powdering in an agate mortar prior to whole-rock measurements. To prevent possible mixing of coarse detrital phases with authigenic 
clays, the samples were not powdered but gently disaggregated. The clay fraction was separated from the crushed material by centrifugation, which involved the addition of Na-metaphosphate to disperse the clays. Further disaggregation was accomplished in an ultrasonic bath. To ensure a uniform cation exchange, clay fractions separated by centrifugation were saturated by $\mathrm{Mg}$ using a solution of $10 \mathrm{~mL}$ of $4 \mathrm{M} \mathrm{MgCl}_{2}$. Suspensions were washed and centrifuged with distilled water at least three times to minimize the free-ion content. The oriented mounts were prepared by pipetting a suspension on glass slides, which were left to dry at $50{ }^{\circ} \mathrm{C}$ prior to their utilization. The measurements were undertaken in air-dried (AD) conditions and after ethylene-glycol (EG) saturation using a Bruker D8 Advance diffractometer installed at the Geoscience Clay Laboratory of Texas Tech University (Lubbock, TX, USA). This instrument features a horizontal goniometer axis and synchronized rotation of both the X-ray source and the detector arms. Measurement parameters consisted of a step scan in the Bragg-Brentano geometry using $\mathrm{CuK} \alpha$ radiation $(40 \mathrm{kV}$ and $40 \mathrm{~mA})$. Sample mounts were scanned at a counting time of $1.8 \mathrm{~s}$ per $0.02^{\circ} 2 \theta$, from 3 to $70^{\circ} 2 \theta$ and from 3 to $30^{\circ} 2 \theta$ for the whole rock and the clay fraction, respectively. The mineral phases were identified using the PDF4+ database.

\subsection{Interpretation and Modeling of XRD Patterns}

X-ray diffraction patterns of clay minerals were examined using methods described by Moore and Reynolds, 1997 [73] and Środoń, 2006 [74]. For chlorite-mineral interpretation, the recommendations of Lagaly et al., 2006 [75] and Meunier, 2007 [76] were followed. To characterize the mixed-layer clay $\mathrm{XRD}$, clay fraction patterns were modeled using Sybilla ${ }^{\circledR}$ software based on the formalism of Drits and Sakharov, 1976 [77]. The modeling included a trial-and-error procedure that provided optimal clay-mineral structural and probability parameters to obtain the best fit between experimental and calculated patterns and of the intensities of the $00 \mathrm{l}$ reflections for each of the clay phases present. For mixed-layer minerals, the number, nature, and stacking sequence of different compositional layers were taken as modifiable values. Experimental spectra were produced using two discrete phases (illite and chlorite) along with a series of low-ordered (R0) illite-smectite (I-S; I-SS; I-SSS), high-ordered (R1 and R3) I-S phases, and chlorite-smectite-smectite (C-SS) following the procedures in Uzarowicz et al., 2012 [78] and Zanoni et al., 2016 [36]. The second S in disordered illite-smectite (R0 I-SS) denotes a multiple type of smectite component differing from the preceding one in terms of charge and, therefore, in terms of $d$ spacing. In other words, expandable layers in R0 I-S are bi-hydrated and in R0 I-SS they are mono- and bi-hydrated (e.g., $[79,80])$. Modeling parameters of mixed-layer minerals consisted of (1) the extent of the preferred orientation of particles on the mounted X-ray slides $\left(\sigma^{*}\right),(2)$ coherent scattering domain sizes (CSDS) expressed in number of layers, and (3) the amounts of illite component in mixed-layer phases, Table 2. Quantification of whole-rock diffractograms (Table A1) is based on the reference intensity ratio (RIR), which considers the ratio between an internal standard (i.e., corundum) and minerals of interest [81]. Conversely, the abundances of clay minerals were reported from clay fraction diffractograms as relative values from modeled samples (Table A2). 
Table 2. Rock-Eval pyrolysis data from analyzed samples from the Midland basin.

\begin{tabular}{|c|c|c|c|c|c|c|c|c|c|c|c|c|c|c|}
\hline Sample & $\begin{array}{l}\text { Depth } \\
\text { (m) }\end{array}$ & $\begin{array}{c}\text { TOC } \\
\text { (wt } \%)\end{array}$ & $\begin{array}{c}\mathrm{HI}(\mathrm{mg} \\
\mathrm{HC} / \mathrm{g} \text { TOC) }\end{array}$ & $\begin{array}{c}\mathrm{OI}(\mathrm{mg} \\
\mathrm{CO} / \mathrm{g} \text { TOC) }\end{array}$ & $\begin{array}{l}\operatorname{Tmax} \\
\left({ }^{\circ} \mathrm{C}\right)\end{array}$ & $\begin{array}{c}\mathrm{S} 1 \\
(\mathrm{mg} \mathrm{HC} / \mathrm{g})\end{array}$ & $\begin{array}{c}\mathrm{S} 2 \\
(\mathrm{mg} \mathrm{HC} / \mathrm{g})\end{array}$ & S3 & S2/S3 & $\begin{array}{l}\text { Production } \\
\text { Index } \\
\text { S1/(S1 + S2) }\end{array}$ & $\begin{array}{c}\text { Calculated } \\
\% \text { Ro* }\end{array}$ & $\begin{array}{c}\text { Calculated } \\
\% \text { Ro }^{\wedge}\end{array}$ & $\begin{array}{c}\text { Estimate } \\
\text { Peak Burial } \\
\text { Temperature } \\
\left({ }^{\circ} \mathrm{C}\right)^{* *}\end{array}$ & $\begin{array}{c}\text { Estimate } \\
\text { Peak Burial } \\
\text { Temperature } \\
\left({ }^{\circ} \mathrm{C}\right)^{\Perp}\end{array}$ \\
\hline T901-7620 & 2323 & 0.71 & 336.07 & 43.15 & 438 & 0.32 & 2.38 & 0.31 & 7.79 & 0.12 & 0.71 & 1.07 & 123 & 137 \\
\hline T901-7641 & 2329 & 0.86 & 350.04 & 40.23 & 440 & 0.47 & 3.00 & 0.35 & 8.70 & 0.14 & 0.75 & 1.11 & 125 & 139 \\
\hline T901-7645 & 2330 & 3.40 & 406.36 & 8.97 & 438 & 1.66 & 13.83 & 0.31 & 45.29 & 0.11 & 0.71 & 1.07 & 123 & 137 \\
\hline T901-7649 & 2331 & 3.73 & 518.21 & 6.86 & 434 & 5.39 & 19.32 & 0.26 & 75.50 & 0.22 & 0.64 & 0.98 & 119 & 134 \\
\hline Т901-7673 & 2339 & 5.85 & 437.15 & 6.22 & 436 & 2.72 & 25.57 & 0.36 & 70.28 & 0.10 & 0.68 & 1.02 & 121 & 136 \\
\hline Т901-7718 & 2352 & 2.17 & 297.76 & 12.70 & 439 & 0.78 & 6.45 & 0.28 & 23.45 & 0.11 & 0.73 & 1.09 & 124 & 138 \\
\hline T901-8156 & 2486 & 3.91 & 306.92 & 9.03 & 439 & 1.69 & 12.01 & 0.35 & 33.97 & 0.12 & 0.73 & 1.09 & 124 & 138 \\
\hline T901-8167 & 2489 & 3.69 & 264.55 & 6.65 & 442 & 1.26 & 9.75 & 0.25 & 39.77 & 0.11 & 0.77 & 1.15 & 126 & 140 \\
\hline T901-8175 & 2492 & 9.16 & 375.14 & 3.85 & 439 & 3.34 & 34.36 & 0.35 & 97.39 & 0.09 & 0.72 & 1.09 & 124 & 138 \\
\hline T901-8217 & 2505 & 3.51 & 311.30 & 9.49 & 442 & 1.25 & 10.92 & 0.33 & 32.81 & 0.10 & 0.77 & 1.15 & 126 & 140 \\
\hline T901-8236 & 2510 & 3.01 & 300.43 & 3.91 & 441 & 2.35 & 18.06 & 0.23 & 76.93 & 0.12 & 0.76 & 1.13 & 125 & 139 \\
\hline T901-8275 & 2522 & 2.22 & 265.95 & 21.13 & 438 & 1.22 & 5.91 & 0.47 & 12.58 & 0.17 & 0.71 & 1.07 & 123 & 137 \\
\hline T901-8289 & 2526 & 1.22 & 319.83 & 28.90 & 438 & 0.91 & 3.89 & 0.35 & 11.07 & 0.19 & 0.71 & 1.07 & 123 & 137 \\
\hline T901-8306 & 2532 & 9.56 & 316.79 & 3.78 & 441 & 4.56 & 30.29 & 0.36 & 83.90 & 0.13 & 0.75 & 1.13 & 125 & 139 \\
\hline T901-8357 & 2547 & 3.23 & 327.18 & 12.98 & 438 & 1.87 & 10.57 & 0.42 & 25.20 & 0.15 & 0.72 & 1.07 & 124 & 137 \\
\hline T401-9004 & 2744 & 0.22 & 133.95 & 108.59 & 347 & 0.08 & 0.30 & 0.24 & 1.23 & 0.21 & & & & \\
\hline T401-9015 & 2748 & 0.15 & 294.84 & 108.23 & 347 & 0.10 & 0.45 & 0.17 & 2.72 & 0.18 & & & & \\
\hline T401-9027 & 2751 & 0.96 & 82.82 & 87.09 & 428 & 0.23 & 0.79 & 0.84 & 0.95 & 0.23 & 0.55 & 0.91 & 114 & 132 \\
\hline T401-9031 & 2753 & 7.69 & 183.12 & 4.43 & 440 & 1.48 & 14.09 & 0.34 & 41.38 & 0.10 & 0.75 & 1.18 & 125 & 141 \\
\hline T401-9034* & 2754 & 0.86 & 40.65 & 15.10 & 441 & 0.14 & 0.35 & 0.13 & 2.69 & 0.29 & 0.76 & 1.22 & 125 & 142 \\
\hline JP11091 & 3381 & 13.57 & 457.39 & 5.20 & 440 & 5.62 & 62.08 & 0.71 & 87.89 & 0.08 & 0.75 & 1.11 & 125 & 139 \\
\hline JP11107 & 3385 & 3.62 & 336.14 & 7.76 & 441 & 1.25 & 12.16 & 0.28 & 43.89 & 0.09 & 0.77 & 1.13 & 126 & 139 \\
\hline JP11118 & 3389 & 1.92 & 137.01 & 24.22 & 442 & 0.45 & 2.63 & 0.46 & 5.66 & 0.15 & 0.78 & 1.15 & 126 & 140 \\
\hline JP11135 & 3394 & 3.70 & 216.00 & 6.00 & 441 & 0.71 & 8.00 & 0.22 & 35.99 & 0.08 & 0.76 & 1.13 & 126 & 139 \\
\hline
\end{tabular}

Abbreviations: TOC—-total organic carbon; HI-hydrogen index; OI-oxygen index; Tmax-temperature at which maximum amount of S2 hydrocarbons are generated; S1—amount of free hydrocarbons released at $200{ }^{\circ} \mathrm{C}$; S2 -hydrocarbon generated by pyrolytic degradation of kerogen; S3-carbon dioxide generated by pyrolytic degradation; S2/S3 = generative types 6.5143 (Jarvie et al., 2018); Calculated $\% \mathrm{R}_{\mathrm{o}}{ }^{\prime}$ from Tmax $=(0.022 \times \mathrm{Tmax})-8.57$ (Lewan and Pawlewicz, 2017); Estimate Peak Burial Temperature $(\mathrm{C}) * *$ using $\% \mathrm{R}_{\mathrm{o}}^{*}=\left(\mathrm{LOG}\left(\% \mathrm{R}_{\mathrm{o}}{ }^{*}\right)+\right.$ 1.68)/0.0124 (Baludikay et al., 2018); Estimate Peak Burial Temperature (C) ${ }^{\wedge}$ using $\% \mathrm{R}_{\mathrm{o}}{ }^{\wedge}=\left(\mathrm{LOG}\left(\% \mathrm{R}_{\mathrm{o}}{ }^{\wedge}\right)+1.68\right) / 0.0124$ (Baludikay et al., 2018). Sample T401-9034 data was obtained by Weatherford Laboratories. 


\subsection{Rock-Eval pyrolysis}

All samples were analyzed at the Institute of Earth Sciences of the University of Lausanne (Switzerland) except T401-9034, which was analyzed by Weatherford Laboratories (Houston, TX, USA). Samples were homogenized using a mortar grinder for Rock-Eval analyses performed using a Rock-Eval 6 pyrolizer (Vinci Technologies) on aliquots of 55 to $70 \mathrm{mg}$ in Incoloy crucibles. Analytical procedures closely followed detailed instructions provided by Ordonez et al., 2019 [82] and primarily include the following: TOC ( $\mathrm{wt} \%$ ), the total content of organic matter in the rock; $\mathrm{S} 1$ (mg HC/g rock), free hydrocarbons contained in the organic matter; $\mathrm{S} 2$ (mg HC/g rock), the amount of hydrocarbons formed by the rock; $\mathrm{S} 3\left(\mathrm{mg} \mathrm{CO} / \mathrm{g}\right.$ rock), $\mathrm{CO}_{2}$ pyrolized; and Tmax $\left({ }^{\circ} \mathrm{C}\right)$, the temperature when the S2 peak is recorded. Additionally, source rock parameters, such as $\mathrm{HI}(\mathrm{mgHC} / \mathrm{g} \mathrm{TOC}), \mathrm{OI}\left(\mathrm{mg} \mathrm{CO}_{2} / \mathrm{g}\right.$ $\mathrm{TOC})$, and PI (S1/S1 + S2), were calculated, to evaluate the type of kerogen and the hydrocarbon generation and expulsion potential $[13,83]$. Traditionally, vitrinite reflectance $\left(\% R_{0}\right)$ is used to infer the maturation of hydrocarbon by means of organic petrography; however, this technique may be time consuming and is dependent on the presence of vitrinite itself [29]. Furthermore, additional maturation indices, such as Rock-Eval (Tmax, HI) and clay mineral maturation, may be used in case of a paucity of $\% R_{o}$ data. Since petrographical $\% R_{o}$ data was not available during this study, calculated $\% R_{o}$ values were determined by Tmax obtained from Rock-Eval pyrolysis using developed formalism $[43,84]$ from data collected in the adjacent Fort Worth Basin, USA. Subsequently, the calculated $\% R_{o}$ was employed to determine peak burial temperatures [85].

\section{Results}

\subsection{Lithofacies}

The Tonya 401 and 901 cores located in the northeastern Midland Basin are geographically separated by approximately $1.5 \mathrm{~km}(1 \mathrm{mi})$ with no evidence of displacement; therefore, the two were combined to create a single stratigraphic section represented by three distinct intervals: the upper (2323-2359 (7620-7741 ft.)), middle (2486-2547 m (8156-8357 ft.)), and lower (2744-2754 m (9003-9041 ft.)) sampling intervals (Figure 4). The upper sampling interval lithofacies are mostly interbedded black siliceous shales and black calcareous shales with occasional limestone and dolomitic intervals. The middle sampling interval lithofacies are predominantly black shales with very thin interbedded limestone and dolomite. These two sections represent the Wolfcamp formation of Permian (upper section) and Pennsylvanian (middle section) ages (Figure 5). In the lowest section, the lithofacies are more variable and consist of grey-black siliceous shale, grey to black calcareous shale, green-grey siltstone, and massive grey limestone, which represent the Barnett formation of Mississippian age. The JP Chilton core interval (3381-3394 m (10,091-11,135 ft.)) (Figure 4) is mostly calcareous-rich shales at the top of the interval with more silica-rich shale at the bottom that overlie massive grey grainstone carbonates (Figure 5). This core interval is part of the Wolfcamp formation within the northwestern Midland Basin. 


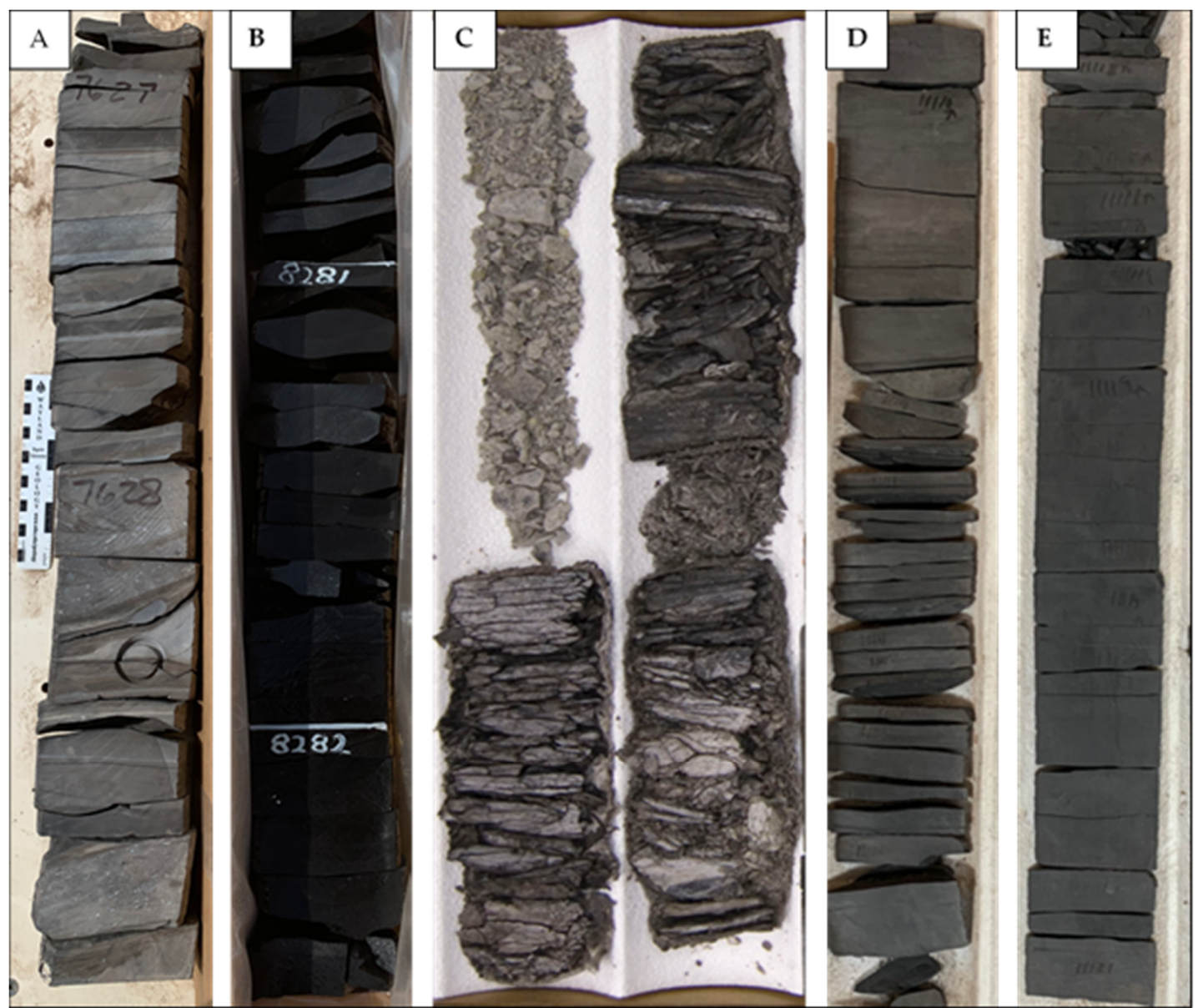

Figure 5. Lithofacies within the Tonya 901 (A,B), Tonya 401 (C), and JP Chilton (D,E) cores. (A) Interbedded Si-rich and Ca-rich shale. (B) Si-rich black shale. (C) Green-grey siltstone and claystone. (D) Ca-rich shale. (E). Si-rich shale.

\subsection{XRD Mineralogy}

\subsubsection{Whole-Rock Fraction}

Whole-rock XRD diffractograms within the Tonya sampling intervals indicate primary phases of quartz, calcite, albite, and clay minerals, with minor phases consisting of pyrite, dolomite, microcline, analcime, and lesser amounts of Fe sulfide and gypsum. Mineral phases and their relative abundances are summarized in Figure 6 with detailed amounts found within Appendix A. Primary phases' presence corresponds well with lithofacies and appear to be mostly controlled by the depositional environment. Hence, the content of quartz and mica are abundant in Si-rich shale facies whereas calcite within Ca-rich facies is largely controlled by the amount of fossiliferous and limestone clasts debris. The minor phase of analcime is primarily found in upper and middle cores of the combined Tonya well (2322.6-2505.4 $\mathrm{m}$ (7620-8236 ft.)) with little presence in the lower sampling interval or the JP Chilton core. Reference intensity ratio (RIR) quantification showed that Wolfcamp formation samples average $40 \%$ quartz, $18.5 \%$ carbonate, and $26 \%$ clay minerals, depending on the prevalence of detrital carbonate, whilst Barnett formation samples average 37\% quartz, 20\% carbonate, and $23 \%$ clay minerals. Whole-rock diffractograms of the JP Chilton core show similar phases to those of the Tonya cores with the occurrence of quartz, calcite, dolomite, K-feldspar, clay, and pyrite and no presence of analcime. RIR quantification displays higher abundances of calcite in the upper portion of the core and dissipating near the bottom of the sampling interval. 


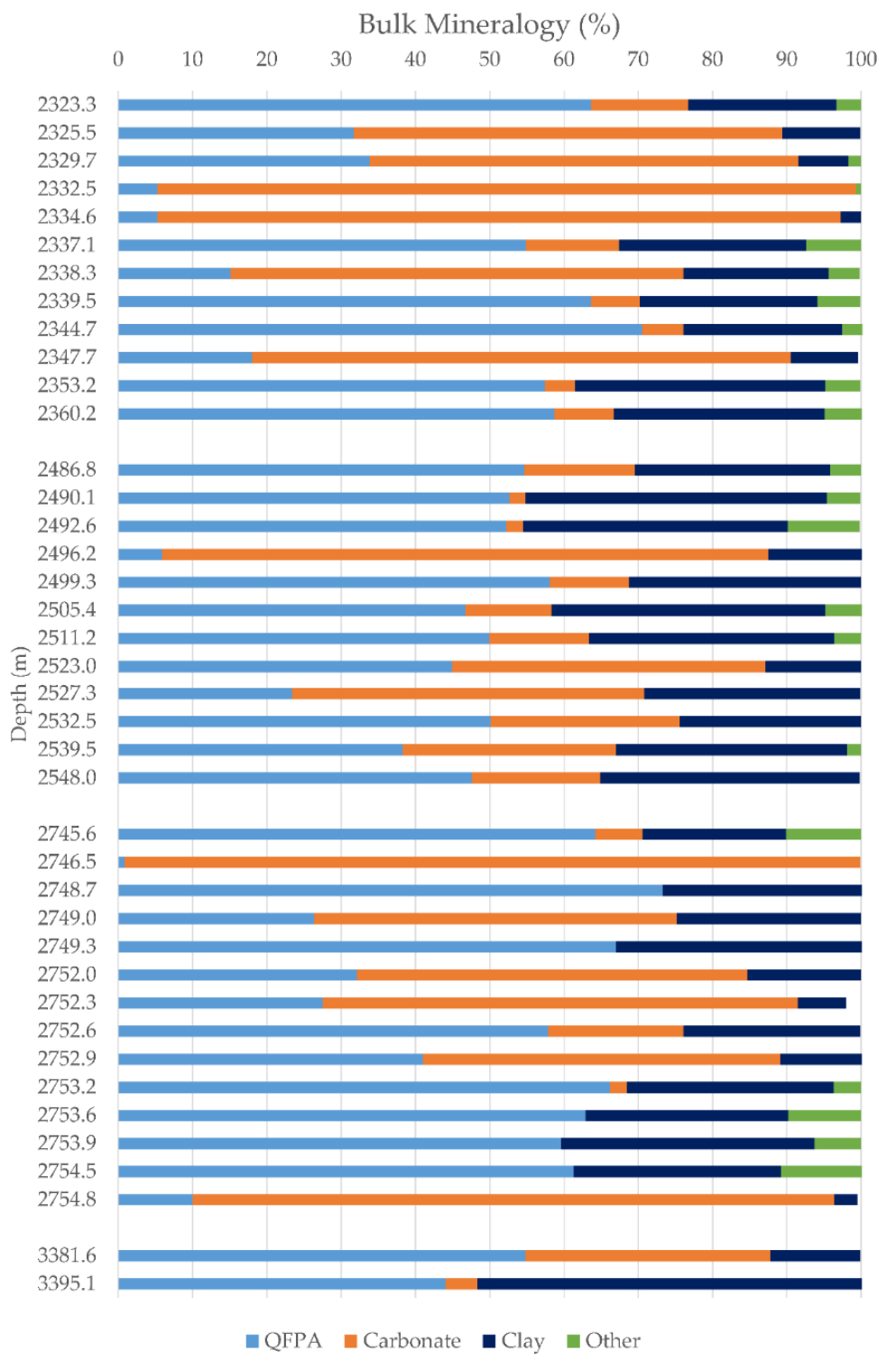

Figure 6. RIR quantifications of representative whole rock samples from the study interval. Phases were combined into four major groups. QFPA = quartz, feldspars, pyrite, apatite; carbonates = calcite and dolomite; clay = mica and clinochlore; other = remaining minor phases, see Appendix A.

\subsubsection{Clay Fraction}

Clay minerals present within the sample interval account for illite, various mixed-interlayered illite-smectite (R0 I-S, R0 I-SS, R0 I-SSS, R1 I-S, and R3 I-S), chlorite, and mixed-layer chlorite-smectite (R0 C-SS). Clay mineral abundances are given in Appendix B. Discrete illite was identified predominantly by the 10 - and $5-\AA$ peaks corresponding to the 001 and 002 reflections (Figure 7) ranging from $0 \%$ to $41.3 \%$. Interstratified mixed-layer phases are recognized by using the criteria of Reynolds and Hower, 1970 [86] featuring the broad diffraction peak near $17 \AA$ appearing in glycolated samples as well as additional broadening of peaks near $10 \AA$. Once identified, pattern fitting and deconvolution of original experimental spectra (Appendix $C$ ) indicated the presence of multiple disordered mixed layered phases (R0 I-S, I-SS, and I-SSS) (Figure 7) throughout the study interval. The disordered mixed layer phases primarily occur within the upper sampling interval of the Tonya core (2322.6-2485.9 m (7620-8156 ft.)) (Figure 8). Additionally, the illite components of R0 I-S and R0 I-SS ranged from 5\% to $25 \%$ and $10 \%$ to $38 \%$, respectively. Furthermore, ordered mixed layered phases of R1 I-S (Figures 7 and 8 ) were recognized by reflections near 11.1 and $13.3 \AA$. These two reflection points indicate a 
long-range ordering of the second-ordered superstructure unit cell of three $10 \AA$ illite layers and one 17 $\AA$ smectite layer [73]. R1 I-S phases mostly occur within the middle sampling interval of the Tonya core (2485.9-2516.4 m (8156-8256 ft.)) and throughout the JP Chilton core (3380.5-3393.9 m (11,091-11,135 $\mathrm{ft}$.$) ). The illite abundance within the R1 I-S phases range from 75-95\%. Long-ordered R3 I-S phases$ were observed solely within the lower Tonya interval (2744.4-2753.3 m (9004-9033 ft.)). This phase contains 92-99\% illite within the R3 I-S phase. Discrete chlorite was identified by peaks at 14.1, 7.1, and $4.5 \AA$, Figure 7. Discrete chlorite begins to appear at $2339 \mathrm{~m}(7673 \mathrm{ft}$.) and ranges from $0.9-5.5 \%$. This phase is most abundant in lower Wolfcamp samples from depths of 2339-3393 m (7673-8256 ft.). Furthermore, mixed-layer C-SS phases were observed primarily within the lower Wolfcamp samples in the Tonya core and lower most samples in the JP Chilton core (Appendix C) and sporadically reached abundances up to $17 \%$.
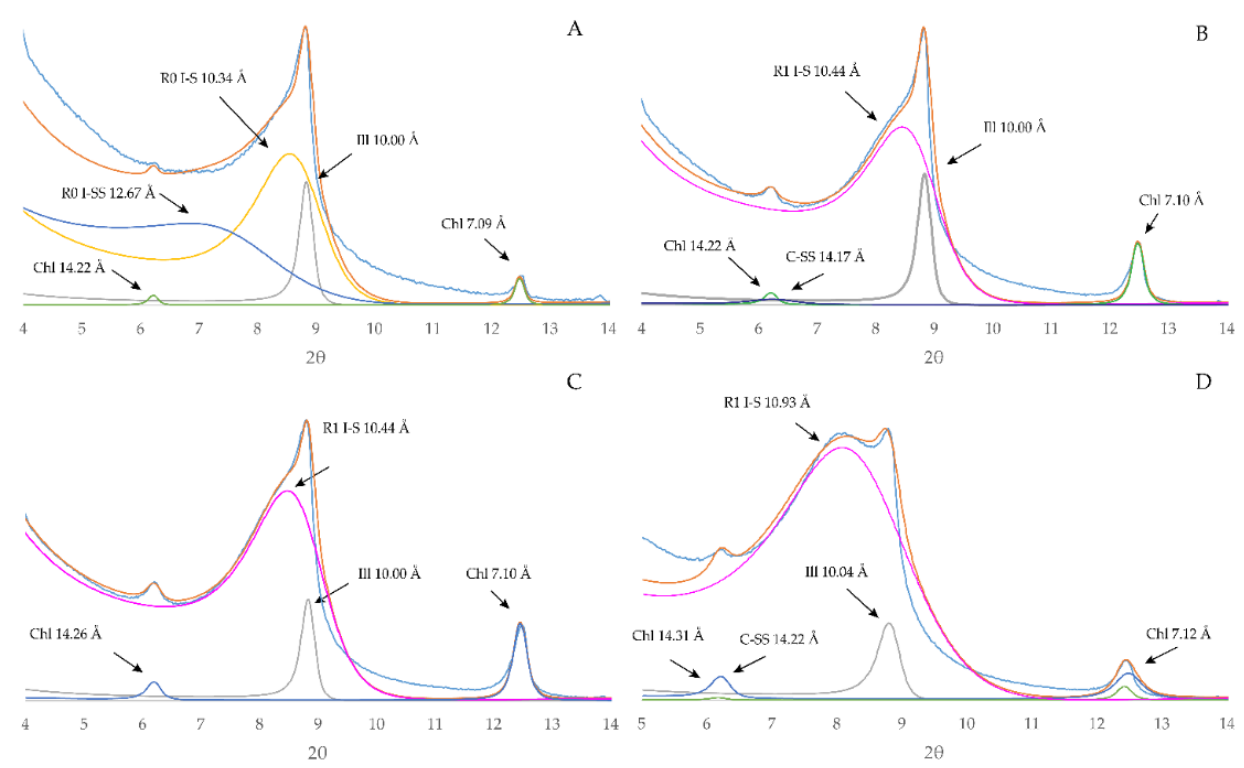

Figure 7. Deconvolution of XRD patterns of clay fraction for four representative samples. (A-T401-7673, B-T401-8197, C-T401-8252, and D-JP Chilton-11118). The experimental XRD pattern is blue with the modeled fit being orange, with phases of illite (grey), chlorite (green), R0 I-S (yellow), R1 I-S (pink), R3 I-S (red), and R0 I-SS (dark blue). 


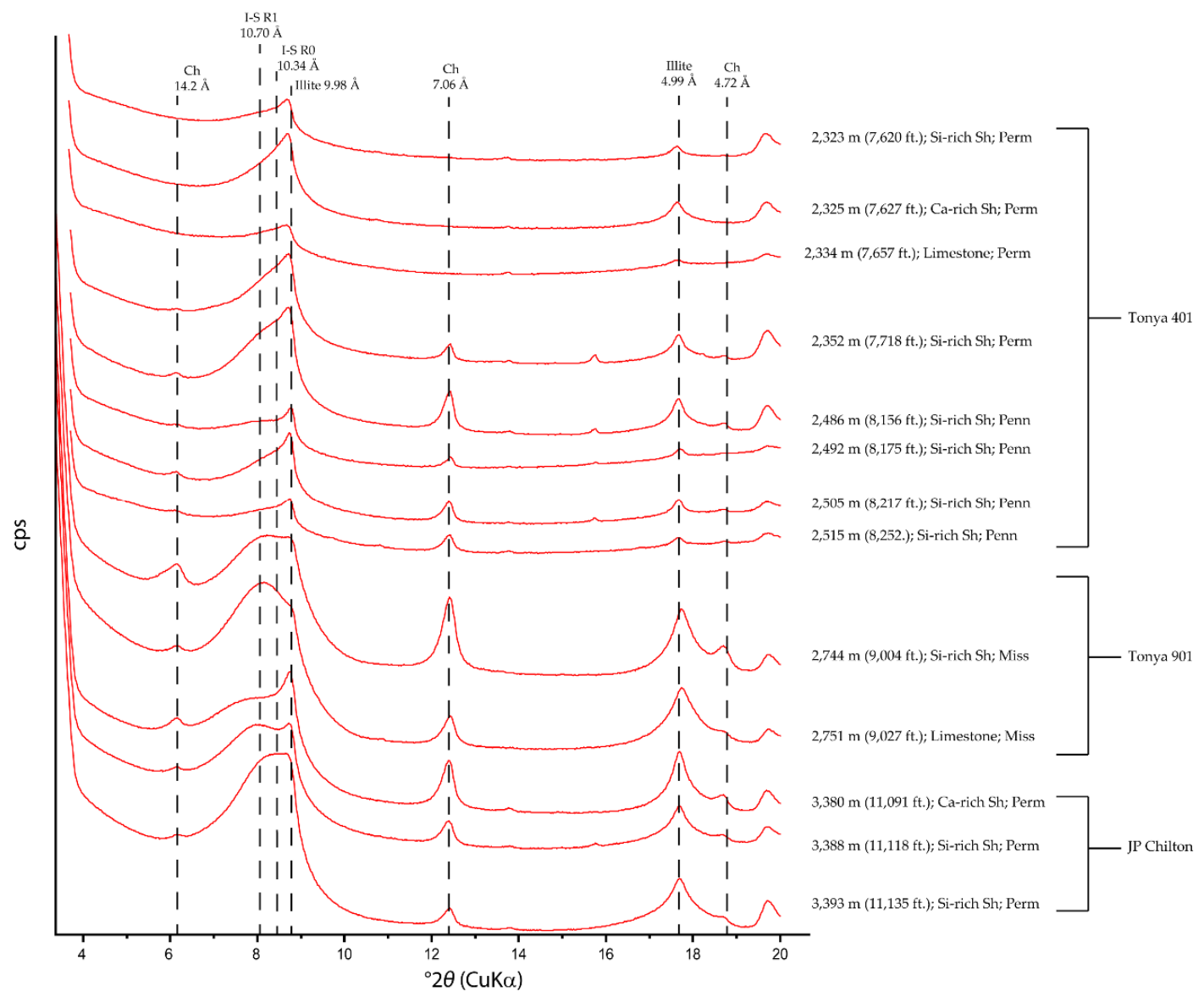

Figure 8. Mineral composition of clay fraction analyzed samples from representative samples. Si-rich $\mathrm{Sh}=$ silica rich shale; Ca-rich $\mathrm{Sh}=$ calcium rich shale, Perm = Permian; Penn = Pennsylvanian, Miss = Mississippian.

\subsection{Rock-Eval Pyrolysis}

TOC values from all samples range between $<1 \mathrm{wt} \%$ and $13.57 \mathrm{wt} \%$ throughout the study interval. The middle sampling interval within the Tonya 901 core from $2486-2547$ m produced the most consistent TOC values, averaging $4.39 \mathrm{wt} \%$ (Table 2). S1 values are mostly consistent, ranging from near 0.50 to $3.34 \mathrm{mgHC} / \mathrm{gTOC}$, except in Tonya 401 samples, where values are extremely low, whereas S2 values range from $0.30-62.08 \mathrm{mgHC} / \mathrm{gTOC}$ and correlate well with TOC amounts. HI amounts typically range from 137 to 518 , with most samples falling within 200 to $400 \mathrm{mgHC} / \mathrm{gTOC}$ except for two samples: T401-9027 and T401-9034. OI values mostly range from 3.78-28.90 mgHC/gTOC, with five samples over 40.23 up to $108.59 \mathrm{mgHC} / \mathrm{gTOC}$. Kerogen types consist primarily of Type II [87-89]. Tmax values range from 434 to $442{ }^{\circ} \mathrm{C}$, with two samples (T401-9004 and T401-9015) at $347^{\circ} \mathrm{C}$. These low Tmax values are possibly due to the very low abundance of organic matter $(<0.22 \mathrm{wt} \%)$ within the samples and disallowing the expulsion of free hydrocarbons or cracking, thus reducing the S2 peak for which Tmax is dependent $[18,90]$. Calculated vitrinite reflectance $\left(\% R_{\mathrm{o}}\right)$ using the Jarvie et al. [84] equation range $0.55-0.78$ (Table 2 ). The Tmax and $\% R_{o}$ values suggest that sediments were exposed to temperatures near the beginning of the oil window ([20] and references therein). The $\% R_{o}$ values when using the Lewan and Pawlewicz [43] equation are slightly higher ranging from 0.91-1.22, indicating later maturation (Table 2). 


\section{Discussion}

\subsection{Clay Mineral Evolution}

The conversion of smectite to illite through a series of mixed-layered I-S is a common diagenetic transformation within sedimentary basins, whereby the conversion dynamics and component ordering are primarily controlled by the increase in temperature, but other factors, such as reservoir characteristics, K availability, or starting composition of smectite, may also affect the conversion process [12,36,91-93]. Therefore, illite-smectite composition and ordering can be utilized as a relative geothermometer to indicate the maximum burial temperatures within a sedimentary basin $[11,12,33,94,95]$. Within the upper Tonya 401 core (2322.6-2359.5 $\mathrm{m}$ (7620-7741 ft.)), the primarily clay component is random ordered (R0) I-S and I-SS (Figure 7). Of these, the illite constituent of R0 I-S averages 90\% (Appendix C). This suggests that analyzed lithofacies within this interval were likely exposed to temperatures near $100{ }^{\circ} \mathrm{C}$ based on the paleogeothermometer calibration of Środon (1999) [12] using the proportion of smectite in I-S (Appendix C). However, with no evident appearance of R1 I-S phases within this upper Tonya 901 sections (2322.6-2359.5 m (7620-7741 ft.)), maximum temperatures likely did not surpass $100-110{ }^{\circ} \mathrm{C}[12,33,96]$. Using a geothermal gradient of $40{ }^{\circ} \mathrm{C} / \mathrm{km}$ for the Permian Basin [71], the maximum burial depths of this interval were less than $2.5 \mathrm{~km}$ and have been and still are at least moderately exposed to mesogenesis [11,12,33,97,98].

Mixed layered R1 I-S phases were observed beginning at $2485.9 \mathrm{~m}(8156 \mathrm{ft}$.) and appear throughout the middle sampling interval of the Tonya 901 (2485.9-2156.4 m (8156-8252 ft.)) core as well as the entire JP Chilton core (3381-3394 m (11,091-11,135 ft.)). The presence of R1 I-S phases implies that facies were exposed to higher paleogeothermal temperatures near or above $100-110{ }^{\circ} \mathrm{C}$ and further mesogenesis [96]. The increased ordering within the two cores can be attributed to a temperature increase to depth within the JP Chilton core and increased residence time (duration of heating) in the Tonya. As mentioned before, for the normal geothermal gradient of $40^{\circ} \mathrm{C} / \mathrm{km}$ [71], the depth for conversion of R0 to R1 (100-110 ${ }^{\circ} \mathrm{C}$, [96]) should surpass $3 \mathrm{~km}$ below the surface. Furthermore, the lack of higher-ordered I-S in the deeper JP Chilton core suggests that both the Tonya and JP Chilton facies within the R1 I-S interval were subjected to the same maximum burial depths, and present-day depths (Tonya, $2485.9 \mathrm{~m}$; JP Chilton, $3380.5 \mathrm{~m}$ ) of core facies reflect asymmetrical deepening of the Midland basin toward the west and uplifting along the Bend arch to the east $[54,67]$.

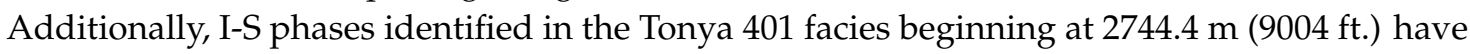
increased illite in I-S, and significantly less smectite (Appendix C) proposes that these facies were exposed to paleotemperatures likely above $130{ }^{\circ} \mathrm{C}$ and depths greater than $4 \mathrm{~km}$ based on models by Hower (1981) [83] and Środon and Eberl, 1987 [99]. These approximations appear to relate well to the calculated $\% R_{o}$ from Tmax using the Jarvie (2018) [84] equation (Table 2), which estimates sediments were exposed to maximum temperatures of near $120^{\circ} \mathrm{C}$ [85] and possible burial depths of $3 \mathrm{~km}$ (40 ${ }^{\circ} \mathrm{C} / \mathrm{km}$ ). However, when applying the Lewan and Pawlewicz [43] equation for calculated $\% R_{\mathrm{o}}$ to data from this study, increases in both calculated $\% R_{o}(0.85-1.15)$ and maximum burial temperatures $\left(129-140^{\circ} \mathrm{C}\right.$ ) (Table 2) were seen. This increase may better correlate with the inferred increase in burial temperatures from clay diagenesis from the Tonya 401 facies but appears to overestimate paleotemperatures for the Tonya 901 and JP Chilton facies. The differences in clay mineral and organic maturation indices may be attributed to various factors. First, the Tonya 401 facies are of Mississippian age and have been exposed to long-term burial and heating regimes since at least Morrowan (Early Bashkirian) time [56], allowing illitization of I-S to steadily increase over approximately $320 \mathrm{Ma}$. Secondly, the calculations used for the $\% \mathrm{R}_{\mathrm{o}}$ data presented here (Table 2 ) were developed from datasets within the Fort Worth basin (Texas, USA) [43,84,100] and have not been calibrated with optical organic petrography data from the Midland basin and thus should be treated as approximations until the direct measurement of $\% \mathrm{R}_{\mathrm{o}}$ can be conducted.

Likewise to illitization, the chloritization of smectite through a series of mixed-layered chlorite-smectite (C-S) to chlorite occurs in sedimentary basins in response to time, temperature, fluid to 
rock ratio, the nature of the initial material, and transformation mechanisms; however, these processes are more complex and limited than those of illitization [34,101]. The widely accepted mechanism of chlorite formation in clastic sediments proposes a continuous increase in the percentage of chlorite layers within the parental smectite material as the burial depth or temperature increases [34]. The temperature of chlorite conversion is unclear; however, studies have suggested that the transformation takes place within eogenetic temperatures beginning near $40^{\circ} \mathrm{C}$ and ending approximately at $120^{\circ} \mathrm{C}$ [34,102-104]. Within the Tonya core, mixed-layer C-SS first appear at $2359.5 \mathrm{~m}$ (7741 ft.), with $41 \%$ of chlorite in C-SS (Appendix B), which indicates that at this depth the rocks commenced to diagenetically alter. As depth increased, the chlorite percentage grew to $64 \%$ at $2491.7 \mathrm{~m}(8175 \mathrm{ft}$.) and stayed consistent at $60-65 \%$ throughout the remainder of the study interval (see Appendix B). These data show that with burial, temperature increased, providing a diagenetic environment for more chlorite layers to be added to C-SS but did not reach a maximum temperature to convert all smectitic layers. While the huge difference (50\%) in the chlorite content of C-S within just $160 \mathrm{~m}$ of the core is hard to explain relying on the present-day prevailing geothermal gradient in the Permian Basin of $40^{\circ} \mathrm{C} / \mathrm{km}$ [71], it is more likely that such an abrupt increase is due to hydrothermal activity or the presence of volcanoclastic component in the Wolfcamp formation [34,70].

Multiple studies have identified the occurrence of volcanic ash and pyroclastic deposits within the upper Wolfcamp formation in both the Midland [70] and Delaware [105] basins, along with the observation of analcime, a zeolite formed by the reaction of volcanic ash with saline water [106] within the 2323-2540 m interval reported here. This suggests that the chlorite-rich mixed-layer chlorite-smectite, which emerges at $2329 \mathrm{~m}$, reflects possible the presence and rapid alteration of volcanoclastic material $[34,36]$, which we relate to the volcanic arc environment that came into being through the collision of Laurentia and Gondwana $[107,108]$. A proposed source area of volcanic material for the Permian Wolfcamp formation is the Sonoran volcanic arc along the southwestern margin of Laurentia [70]. Additionally, arc-related environments associated with the convergence of Laurentia and Gondwana directly south of the Midland basin may propose a more proximal source volcanic material during the Late Pennsylvanian to Early Permian (e.g., [109-112]). In addition to C-S, discrete chlorite has also been reported in the upper Wolfcamp formation and is likely detrital in nature due to the mineral being relatively slow to undergo weathering and alteration during relatively short transport [113]. Detrital chlorite is generally transported from the continents into the oceans as a part of metamorphic or hydrothermally altered igneous lithic fragments, which essentially break down to fine-grained marine sediment $[114,115]$. Discrete chlorite phases reported here were possibly derived from metamorphic environments to the south of the Midland basin along the southern Laurentian and northern Gondwanan collisions zones during the formation of Pangea at the beginning of the Pennsylvanian [116].

\subsection{Source Rock Potential}

The capability of source rocks to generate a significant amount of hydrocarbons and become productive unconventional reservoirs is commonly assessed in terms of organic matter quantity, quality, and maturity, e.g., $[18,117]$. These parameters are mostly related to the depositional environment where the organic matter forms, as well as, the diagenetic processes experienced by the rock. Variation of these parameters can considerably control the properties of an unconventional reservoir and influence heterogenic organic-lean intervals alternating with organic-rich intervals $[44,118,119]$. The total organic content (TOC) within the Tonya study interval $(2323-2754 \mathrm{~m})$ averages $3.31 \mathrm{wt} \%(\mathrm{n}=20)($ Table 2$)$; however, the highest TOC values appear to be within the Ca-rich shales $(4.01 \mathrm{wt} \%, \mathrm{n}=4)$ versus the Si-rich shales (3.39 wt $\%, n=13$ ) (Figure 9). These are contrasting results from Baumgardner and Hamlin [119] who reported higher TOC values in Si-rich mudrocks (3.0 wt $\%)$ and lower TOC values in Ca-rich mudrocks ( $2.0 \mathrm{wt} \%$ ) of Wolfcamp and Leonardian age rocks. These comparisons, however, should be investigated further due to the complexity of depositional systems within the Midland basin affecting the lateral variation in debris flows as well as the local depositional conditions affecting 
bottom water anoxia for the preservation of organic matter [18]. Along with TOC, S2 (hydrocarbon potential index) and production index (PI) may be used to determine if source rocks have the potential to generate and expel hydrocarbons [117]. First, S2 results are not shown to be dependent on lithofacies but overall increase within the younger Pennsylvanian - Permian sediments within the Tonya 901 and JP Chilton cores (Figure 9). Second, the PI values show that facies within Pennsylvanian-Permian Tonya 401 interval (Figure 9) have the best potential to expulse hydrocarbons falling within ranges of suggested by Peters and Cassa [117].

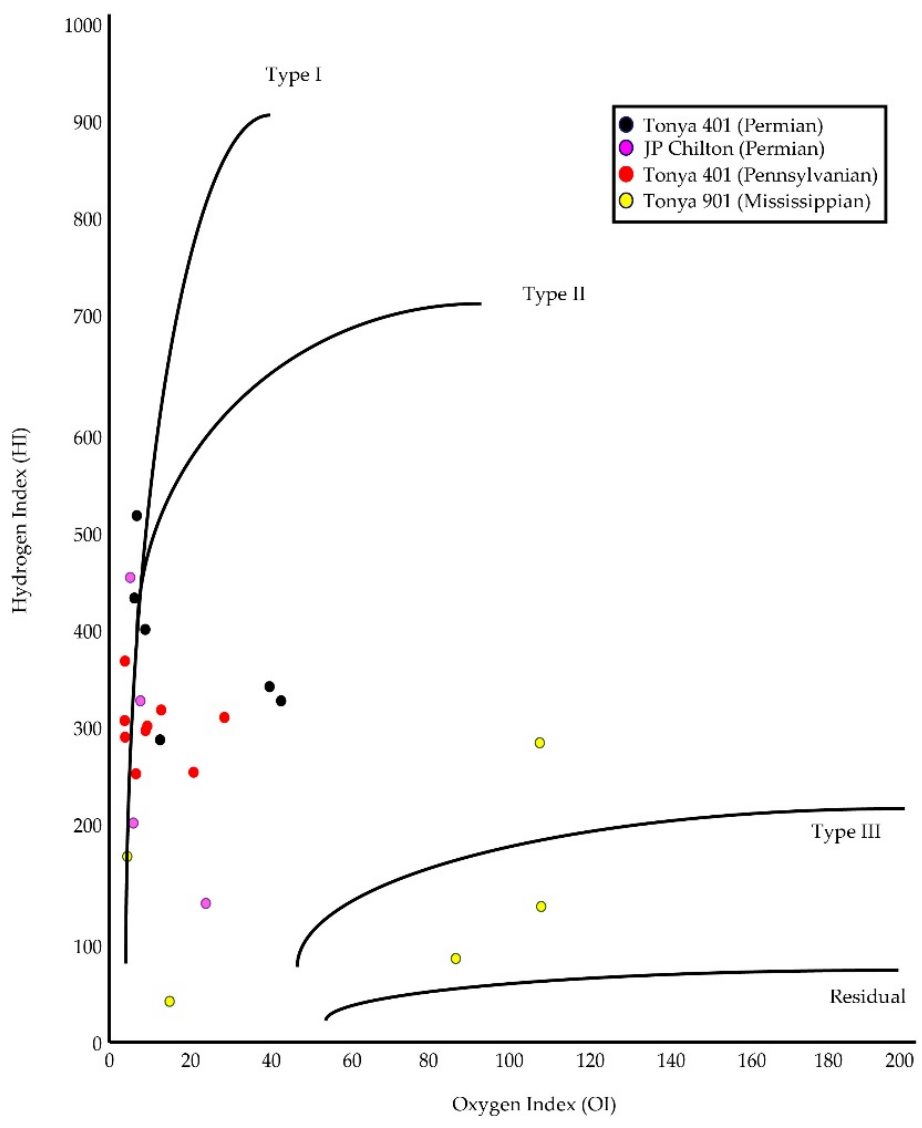

Figure 9. Pseudo-van Krevelen diagram modified from Espitalié et al., 1986 [87].

Kerogen types are useful in source rock assessment to determine which type of hydrocarbons are likely to form during thermal maturation $[18,109,111]$ based on hydrogen and oxygen indices obtained from pyrolysis [26,117]. Pseudo-van Krevelen diagram results (Figure 10) shows that kerogen types are primarily type II and are oil prone upon reaching thermal maturation. Moreover, the kerogen types do not appear to be lithofacies dependent. The use of hydrogen and oxygen indices can also be used to infer changes in temperature with depth [120]. The evolution from more abundant HI within the Tonya 901 (Permian) core to lower concentrations of HI in the Tonya 401 (Mississippian) core shows a clear picture of increasing temperature with depth and time, thus indicating more mature facies (Figure 11). Furthermore, the variation in $\mathrm{HI}$ is likely a result of a temperature increase than a change in the depositional environment [120]. Furthermore, Tmax values stay rather consistent throughout the stratigraphic interval uniformly, further indicating early to middle oil conditions and maturation due to loss of HI (Figure 12). 

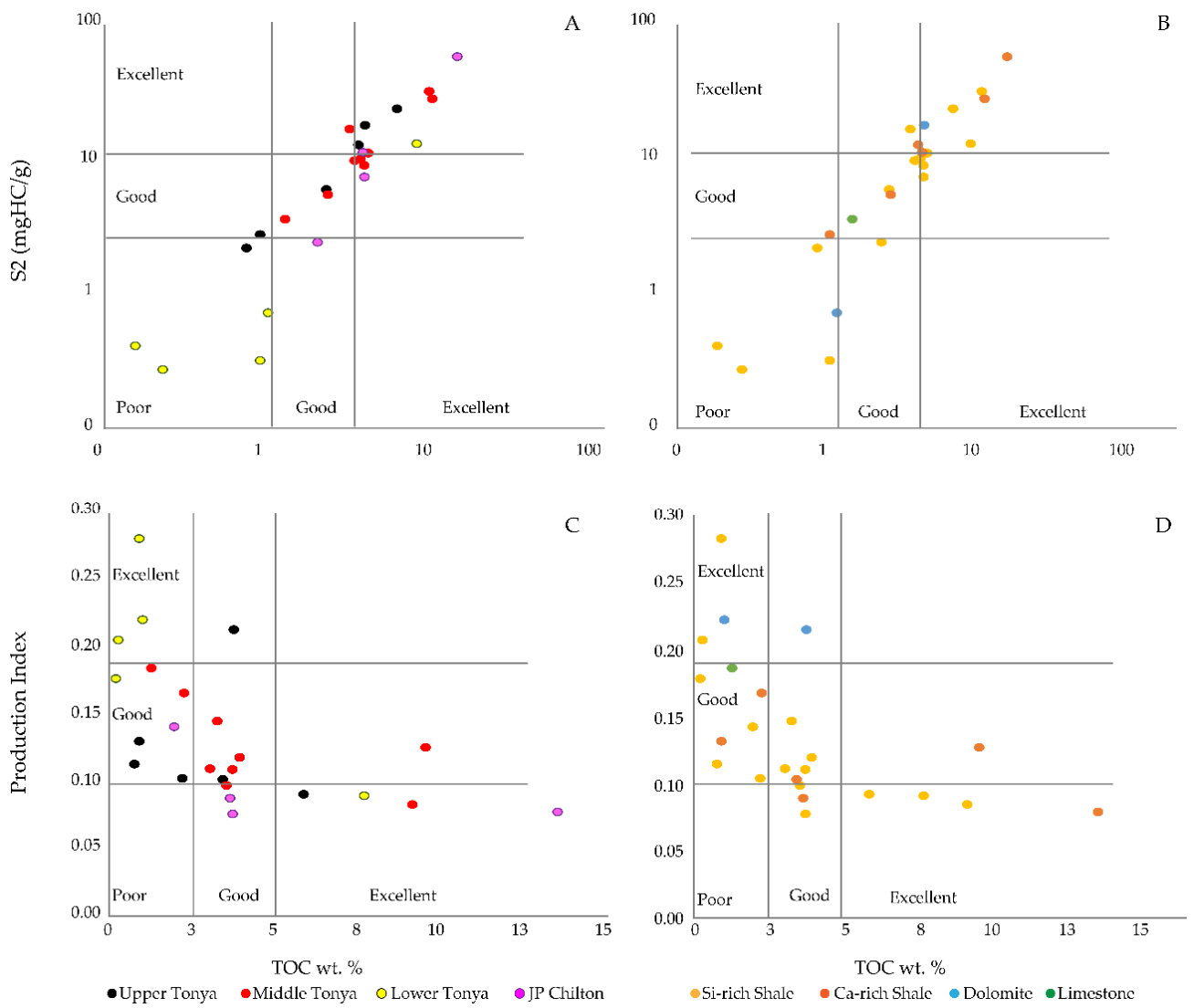

Figure 10. Source rock evaluation indices sorted by depth and lithofacies modified from Peters and Cassa (1994) [117] and Peters (1998) [90]. (A,B) Display of S2 yields increasing with TOC wt. \% and indicate good potential for Permian and Pennsylvanian age sediments regardless of lithofacies. (C,D) Production index versus TOC $w t \%$ plots show that samples have generally good potential for oil generation (0.10-0.30) with moderate to good potential for sizeable expulsion (TOC $>3 \%$ ) despite of lithofacies and depth.

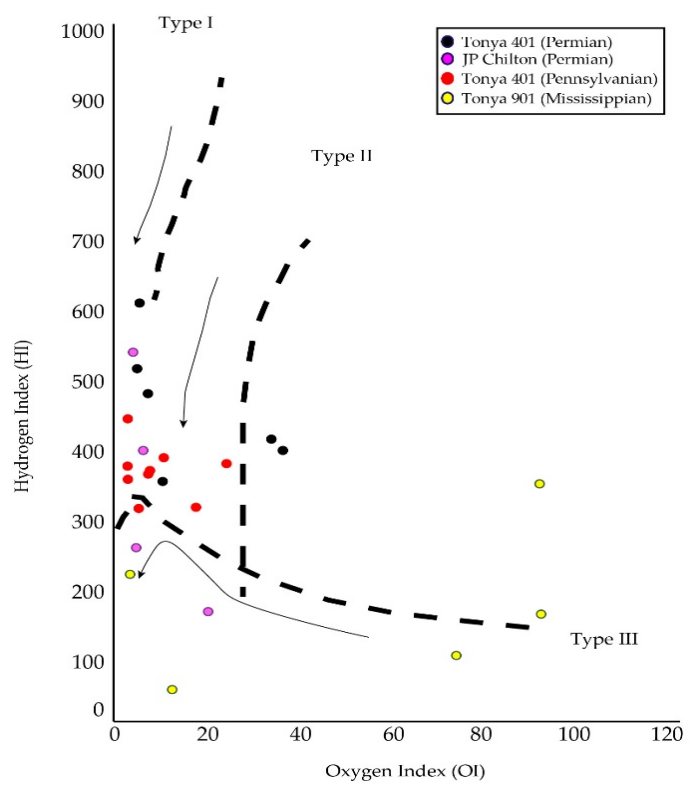

Figure 11. Organic matter types with arrows indicating the progression of maturation modified from Taylor et al., 1998 [120]. 


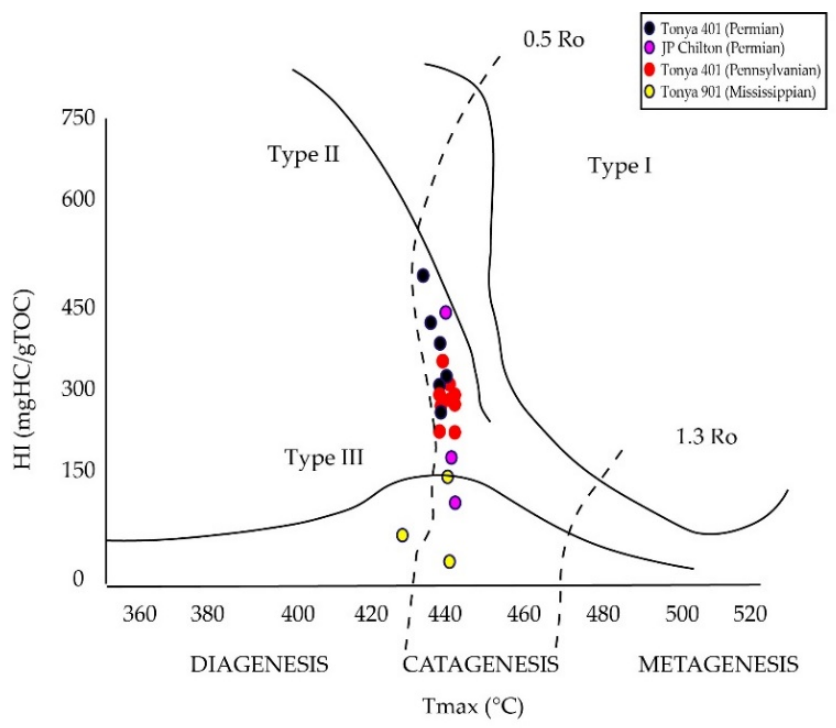

Figure 12. Cross plot diagram of HI versus Tmax modified from Espitalié et al., 1986 [88]. Tmax does not vary through the stratigraphic section and indicates primarily early to middle oil window conditions.

Tmax from Rock-Eval pyrolysis along with OM petrography have been used to develop empirical formulas for calculating $\% R_{o}$ for when more sufficient data is unavailable $[30,43,85]$. Additionally, peak burial temperature equations have also been established using $\% \mathrm{R}_{\mathrm{o}}$ [85] to provide useful tools for insights into the thermal evolution and source rock generation potential of different lithofacies and sedimentary basins for oil and gas exploration [20,24]. Jarvie, 2018 [84] developed an equation for calculated $\% R_{\mathrm{o}}$ (calculated $\% \mathrm{R}_{\mathrm{o}}=(0.0165 \times$ Tmax $\left.)-6.5143\right)$ using Rock-Eval pyrolysis data sets from the Barnett Formation (Fort Worth Basin, USA) for rocks within the $430-485{ }^{\circ} \mathrm{C}$ Tmax window. When this equation is applied to samples from this study, calculated $\% R_{o}$ ranges from $0.55-0.78$ within Tonya cores and $0.74-0.78$ in the JP Chilton core (Table 2, Figure 13), again suggesting early to peak oil window maturations [117]. As mentioned before, however, when the Lewan and Pawlewicz [43] equation was applied, calculated $\% R_{o}$ values were higher (0.85-1.15) (Table 2, Figure 13). However, when clay mineral indices are applied in addition to calculated $\% R_{0}$, the calculated $\% R_{0}$ from Jarvie [84] appear to fit well with the R0 to R1 I-S maturation index $\left(100-110^{\circ} \mathrm{C}\right)$ of early oil window maturation within the Tonya 901 and JP Chilton cores. Further, the increase in illite component in R1 I-S does suggest more heating to Tonya 901 facies, thus the higher $\% R_{o}$ values using the Lewan and Pawlewicz [43] equation may reflect more correlatable thermal indices.

The discrepancies in the calculated $\% \mathrm{R}_{\mathrm{o}}$ formulas used here further indicated the importance of a secondary maturation index to check common organic matter maturation indices $[13,20,21,33,97]$. Organic matter maturation begins earlier due to increased temperatures than silicate minerals. Additionally, relationships of Tmax and clay mineral evolution are not clearly defined [121] and the interaction between kerogen and mixed-layer I-S phases can differ significantly due to reaction kinetics $[13,122]$. Furthermore, the importance of the pyrolysis program especially in shale lithologies has been shown to affect the quality of data $[18,123]$. Carvajal-Ortiz and Gentzis (2018) [123] showed that contrasting Rock-Eval methods yielded significantly different in data when being applied to shale lithologies. Therefore, calculated $\% R_{o}$ values determined from pyrolysis data should be further verified. Finally, it should be noted that the equations stated before have been applied to rocks within the Midland Basin $[43,85]$ but have not been verified due to the scarcity of optical organic petrography within the basin $[23,30]$. 


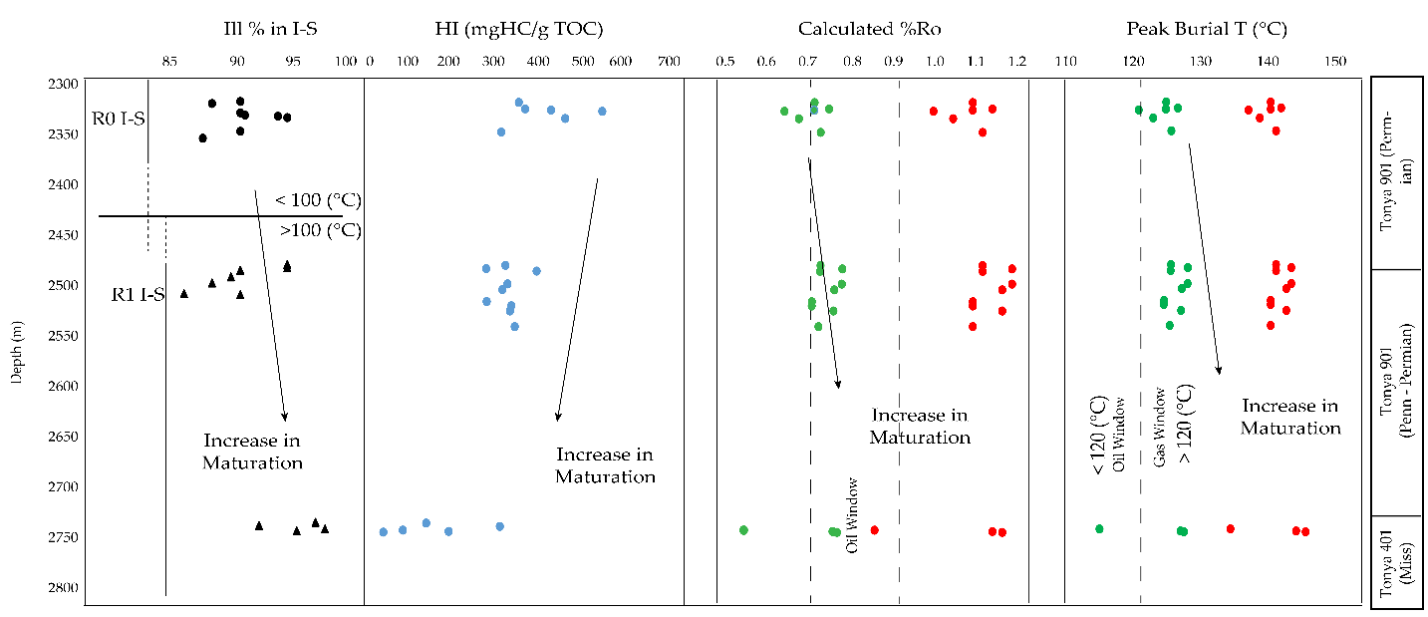

Figure 13. Maturation index data from three cores spanning the study interval. Progressive ordering of I-S corresponds well with an increase of temperature proxies with depth. Calculated $\% \mathrm{R}_{\mathrm{O}}$ after Jarvie (2018) (calculated $\% R_{O}=(0.0165 \times$ Tmax $\left.)-6.5143\right)$ (green dots) and after Lewan and Pawlewicz (2017) (calculated $\left.\% \mathrm{R}_{\mathrm{O}}=(0.022 \times \mathrm{Tmax})-8.57\right)($ red dots $)$. Calculated peak burial temperature $\left(\mathrm{T}\left({ }^{\circ} \mathrm{C}\right)=\right.$ $\left.\left(\ln \left(v \% R_{o}\right)+1.68\right) / 0.0124\right)$ after Barker and Pawlewicz (1994) [80].

\subsection{Correlation of Inorganic and Organic Indices}

The use of Rock-Eval pyrolysis data, vitrinite reflectance $\left(\% \mathrm{R}_{\mathrm{o}}\right)$, and illite-smectite mineralogy have been widely used to determine thermal maturation and evolution in sedimentary basins $[13,20,24,30,33$, $43,96,97]$. The percentage of illite in I-S typically increases with increased $\% R_{o}$ and Tmax and decreases with decreased $\mathrm{HI}$ during burial and increased temperatures (Figure 13). Moreover, the changes from R0 to R1 I-S occurring near $100{ }^{\circ} \mathrm{C}-110{ }^{\circ} \mathrm{C}, 0.5-0.65 \% \mathrm{R}_{\mathrm{o}}$, and Tmax of $430{ }^{\circ} \mathrm{C}-435{ }^{\circ} \mathrm{C}$ coincide closely with the onset of catagenesis and onset of the oil generation window [11-13,33,96,97,117]. Within the Tonya 901 cores, the thermal transition temperature is represented well between the upper (Permian) and lower (Pennsylvanian) cores, with the disappearance of R0 and appearance of R1 representing the transition from eogenesis to mesogenesis and temperatures of at least $100^{\circ} \mathrm{C}$ under normal geothermal conditions [1,24]. The steady increase in the illite component in I-S also indicates a rise in temperatures. Organic data from Tonya 901 cores show a trend of increasing temperature by the loss of HI from the upper (Permian) to lower (Pennsylvanian) facies. Tmax values throughout the cores display a very faint increase and are likely suppressed due to the overall increase in maturation depicted by the loss of $\mathrm{HI}$ and subsequent loss of expelled hydrocarbons before pyrolysis, especially in the Mississippian aged Tonya 401 samples. Accordingly, calculated $\% \mathrm{R}_{\mathrm{o}}$ values should also be suppressed due to the lower Tmax values from which they are derived. Therefore, $\% R_{o}$ values calculated from Jarive (2018) [84] are likely lower than actual $\% R_{o}$ and calculated $\% R_{o}$ from Lewan and Pewlewicz (2017) [43] may be abundantly higher. The transition of R0 to R1 I-S near $100 \mathrm{C}$ suggests $\% \mathrm{R}_{\mathrm{o}}$ values of near 1.0 for which uncorrected calculated \% $R_{\mathrm{o}}$ Lewan and Pewlewicz [43] are closest to clay mineral maturation but should be taken only as approximation until further OM petrography is conducted and equations are calibrated for samples from the Midland basin.

\section{Conclusions}

Three cores from the northern Midland Basin spanning from the Late Mississippian to Early Permian were sampled to acquire the whole-rock and fine-grain $(<2 \mu \mathrm{m})$ mineral assemblages along with geochemical organic characteristics to better understand the robust diagenetic and thermal evolution of the Permian Basin. Petrological and XRD measurements of whole-rock fractions showed varied lithofaices of Si-rich and Ca-rich shale with thin intervals of limestone and dolomite. Clay mineral assemblages consist of discrete phases of illite and chlorite throughout the study interval. XRD pattern modeling of fine-grain fractions displays complex mixed-layered illite-smectite (I-S), I-SS, and 
I-SSS, with progressive ordering from R0 to R1, with accompanied chlorite-smectite-smectite (C-SS). Geochemical analysis of organic matter through Rock-Eval pyrolysis showed primarily TOC-rich sediments of mainly type II kerogens with limited type III. Calculated $\% R_{o}$ appears to be appropriate when applying the Jarvie [79] equation based on the transition and appearance of R0 to R1 I-S. However, this calculation appears to be inadequate when applied to older-age sediments due to the appearance of long-range ordered I-S. However, when applying the Lewan and Pawlewicz [41] equation, the calculated $\% \mathrm{R}_{\mathrm{o}}$ values are higher and appear to correspond closer to observed clay mineral indices, which suggests further investigation into these calculations for use in the Permian Basin. Using I-S, Tmax, calculated $\% \mathrm{R}_{\mathrm{o}}$, and $\mathrm{HI}$ maturation indices, sediments were exposed to sufficient heating for early maturation of hydrocarbons and possibly higher temperatures within the oldest age sediments. Progressive ordering of I-S also implies that lithofacies experienced transformation through eogenesis to mesogenesis conditions and maximum burial paleotemperatures ranging from $<100^{\circ} \mathrm{C}$ to near $140{ }^{\circ} \mathrm{C}$ and maximum burial depths from $2.5-4 \mathrm{~km}$. This study shows the importance of using two dependent maturation indices (organic and mineral) when investigating the modifications of fine-grained source rocks. In future work, measured $\% \mathrm{R}_{\mathrm{o}}$ along with kerogen type identification should be conducted in order to fully understand the nature of organic matter diagenesis. Furthermore, these findings show that clay mineral diagenesis can be applied and be of practical use to better understand regional subbasins within the larger Permian Basin and reconstruct the complex burial history in context to the geotectonic evolution of the southern margin of Laurentia.

Author Contributions: Conceptualization, B.Š. and H.G.; Data curation, H.G.; Formal analysis, H.G., G.Z., and T.A.; Funding acquisition, H.G. and B.Š.; Supervision, B.Š.; Writing—original draft, H.G. and B.Š.; Writing—review and editing, H.G., B.Š., and S.O.-S. All authors have read and agreed to the published version of the manuscript.

Funding: This research was funded by Texas Tech University, AAPG-Grants-in-Aid, SPWLA Research Funds, and the Texas Academy of Science.

Acknowledgments: The authors would like to thank the Geology department at Wayland Baptist University (Plainview, TX, USA) and Tim Walsh for access and use of cores for observations, sampling, and additional geochemical and well log data. The constructive reviews by three anonymous reviewers contributed significantly to the manuscript quality.

Conflicts of Interest: The authors declare no conflict of interest. 


\section{Appendix A}

Table A1. Relative mineral abundances determined by RIR of analyzed samples from the Midland Basin.

\begin{tabular}{|c|c|c|c|c|c|c|c|c|c|c|c|c|}
\hline Sample & Depth (m) & Lithofacies & Qtz & Cal & Dol & Feldspar & Py & Mca & Chl & Gyp & Jar & Flu \\
\hline T401-7620 & 2322.6 & Si-rich Sh & 51.4 & 10.6 & 2.4 & 4.7 & 7.6 & 16.5 & 3.5 & 0.0 & 0.0 & 0.0 \\
\hline T401-7627 & 2324.7 & Ca-rich Sh & 23.1 & 53.3 & 4.4 & 1.7 & 6.9 & 10.5 & 0.0 & 0.0 & 0.0 & 0.0 \\
\hline T401-7641 & 2328.9 & Ca-rich Sh & 29.1 & 56.0 & 1.7 & 2.3 & 2.5 & 6.7 & 0.0 & 0.0 & 0.0 & 0.0 \\
\hline T401-7650 & 2331.7 & Limestone & 4.8 & 94.0 & 0.0 & 0.5 & 0.0 & 0.0 & 0.0 & 0.0 & 0.0 & 0.0 \\
\hline T401-7657 & 2333.9 & Limestone & 3.2 & 91.4 & 0.5 & 0.8 & 1.3 & 2.8 & 0.0 & 0.0 & 0.0 & 0.0 \\
\hline T401-7665 & 2336.3 & Si-rich Sh & 40.3 & 9.0 & 3.5 & 4.9 & 9.7 & 25.2 & 0.0 & 0.0 & 0.0 & 0.0 \\
\hline T401-7669 & 2337.5 & Dolomite & 6.6 & 10.4 & 50.6 & 2.5 & 6.0 & 19.5 & 0.0 & 0.0 & 0.0 & 0.0 \\
\hline T401-7673 & 2338.7 & Si-rich Sh & 50.2 & 4.0 & 2.5 & 5.3 & 8.2 & 17.7 & 6.2 & 0.0 & 0.0 & 0.0 \\
\hline T401-7690 & 2343.9 & Si-rich Sh & 61.2 & 1.9 & 3.7 & 3.9 & 5.4 & 18.4 & 2.9 & 0.0 & 0.0 & 0.0 \\
\hline T401-7700 & 2346.9 & Limestone & 12.0 & 65.9 & 6.6 & 2.9 & 3.1 & 9.1 & 0.0 & 0.0 & 0.0 & 0.0 \\
\hline T401-7718 & 2352.4 & Si-rich Sh & 44.3 & 1.2 & 2.9 & 5.4 & 7.7 & 26.6 & 7.1 & 0.0 & 0.0 & 0.0 \\
\hline T401-7741 & 2359.5 & Si-rich Sh & 44.3 & 5.5 & 2.5 & 5.6 & 8.8 & 19.4 & 9.0 & 0.0 & 0.0 & 0.0 \\
\hline T401-8156 & 2485.9 & Si-rich Sh & 42.3 & 11.5 & 3.3 & 5.1 & 7.3 & 17.9 & 8.4 & 0.0 & 0.0 & 0.0 \\
\hline T401-8167 & 2489.3 & Si-rich Sh & 41.3 & 0.0 & 2.1 & 5.3 & 6.1 & 30.4 & 10.2 & 0.0 & 0.0 & 0.0 \\
\hline T401-8175 & 2491.7 & Si-rich Sh & 37.3 & 0.0 & 2.3 & 5.2 & 9.7 & 26.8 & 8.8 & 0.0 & 0.0 & 0.0 \\
\hline T401-8187 & 2495.3 & Dolomite & 3.6 & 7.7 & 73.9 & 2.3 & 0.0 & 12.6 & 0.0 & 0.0 & 0.0 & 0.0 \\
\hline T401-8197 & 2498.4 & Si-rich Sh & 45.2 & 7.6 & 3.1 & 6.0 & 6.9 & 22.4 & 8.8 & 0.0 & 0.0 & 0.0 \\
\hline T401-8217 & 2504.5 & Si-rich Sh & 34.0 & 6.3 & 5.3 & 4.8 & 7.9 & 28.0 & 8.9 & 0.0 & 0.0 & 0.0 \\
\hline T401-8236 & 2510.3 & Si-rich Sh & 34.9 & 10.2 & 3.3 & 5.8 & 9.2 & 24.4 & 8.6 & 0.0 & 0.0 & 0.0 \\
\hline T401-8275 & 2522.2 & Ca-rich Sh & 32.7 & 39.8 & 2.4 & 2.5 & 9.7 & 12.9 & 0.0 & 0.0 & 0.0 & 0.0 \\
\hline T401-8289 & 2526.4 & Dolomite & 12.8 & 11.6 & 35.8 & 3.4 & 7.2 & 20.9 & 8.2 & 0.0 & 0.0 & 0.0 \\
\hline T401-8306 & 2449.3 & Ca-rich Sh & 39.5 & 22.6 & 2.9 & 5.5 & 5.1 & 17.3 & 7.1 & 0.0 & 0.0 & 0.0 \\
\hline T401-8329 & 2538.6 & Ca-rich Sh & 28.1 & 25.5 & 3.2 & 3.8 & 6.4 & 22.1 & 9.0 & 0.0 & 0.0 & 0.0 \\
\hline T401-8357 & 2547.2 & Si-rich Sh & 34.3 & 13.4 & 3.9 & 5.5 & 7.8 & 25.3 & 9.6 & 0.0 & 0.0 & 0.0 \\
\hline T901-9005 & 2745.6 & Si-rich Sh & 53.6 & 6.4 & 0.0 & 8.1 & 2.5 & 19.3 & 0.0 & 0.0 & 0.0 & 10.1 \\
\hline T901-9008 & 2746.5 & Limestone & 0.5 & 99.1 & 0.0 & 0.0 & 0.3 & 0.0 & 0.0 & 0.0 & 0.0 & 0.0 \\
\hline T901-9015 & 2748.7 & Si-rich Sh & 57.0 & 0.0 & 0.0 & 13.5 & 2.8 & 26.8 & 0.0 & 0.0 & 0.0 & 0.0 \\
\hline T901-9016 & 2749.0 & Ca-rich Sh & 18.5 & 48.8 & 0.0 & 6.3 & 1.6 & 24.8 & 0.0 & 0.0 & 0.0 & 0.0 \\
\hline T901-9017 & 2749.3 & Si-rich Sh & 49.3 & 0.0 & 0.0 & 14.2 & 3.5 & 33.1 & 0.0 & 0.0 & 0.0 & 0.0 \\
\hline T901-9026 & 2752.0 & Limestone & 22.1 & 52.6 & 0.0 & 5.5 & 4.5 & 11.3 & 4.0 & 0.0 & 0.0 & 0.0 \\
\hline T901-9027 & 2752.3 & Limestone & 22.5 & 64.0 & 0.0 & 1.9 & 3.1 & 6.1 & 0.4 & 0.0 & 0.0 & 0.0 \\
\hline T901-9028 & 2752.6 & Si-rich Sh & 43.8 & 18.2 & 0.0 & 7.5 & 6.6 & 21.6 & 2.2 & 0.0 & 0.0 & 0.0 \\
\hline
\end{tabular}


Table A1. Cont.

\begin{tabular}{|c|c|c|c|c|c|c|c|c|c|c|c|c|}
\hline Sample & Depth (m) & Lithofacies & Qtz & Cal & Dol & Feldspar & Py & Mca & Chl & Gyp & Jar & Flu \\
\hline T901-9029 & 2752.9 & Limestone & 32.8 & 48.1 & 0.0 & 4.6 & 3.6 & 9.3 & 1.7 & 0.0 & 0.0 & 0.0 \\
\hline T901-9030 & 2753.2 & Si-rich Sh & 42.6 & 0.0 & 2.3 & 5.4 & 14.5 & 23.9 & 0.0 & 3.7 & 3.7 & 0.0 \\
\hline T901-9031 & 2753.6 & Si-rich Sh & 33.4 & 0.0 & 0.0 & 10.0 & 14.4 & 27.3 & 0.0 & 9.8 & 5.1 & 0.0 \\
\hline T901-9032 & 2753.9 & Si-rich Sh & 36.3 & 0.0 & 0.0 & 13.4 & 4.3 & 34.1 & 0.0 & 6.3 & 5.6 & 0.0 \\
\hline T901-9034 & 2754.5 & Si-rich Sh & 38.9 & 0.0 & 0.0 & 9.7 & 12.7 & 27.9 & 0.0 & 10.9 & 0.0 & 0.0 \\
\hline T901-9035 & 2754.8 & Limestone & 9.6 & 86.4 & 0.0 & 0.0 & 0.4 & 2.6 & 0.5 & 0.0 & 0.0 & 0.0 \\
\hline JP-11091 & 3380.5 & Ca-rich Sh & 37.4 & 22.7 & 10.3 & 14.9 & 2.5 & 8.7 & 3.4 & 0.0 & 0.0 & 0.0 \\
\hline JP-11135 & 3393.9 & Si-rich Sh & 15.0 & 0.7 & 3.5 & 20.4 & 8.7 & 48.3 & 3.5 & 0.0 & 0.0 & 0.0 \\
\hline
\end{tabular}

Abbreviations: $\mathrm{Qtz}=$ quartz; $\mathrm{Cal}=$ calcite Dol = dolomite; $\mathrm{Alb}=$ albite; Mic = microcline; Py = pyrite; Mca = mica-group mineral; Chl = chlorite; Anl = analcime; Gyp = gypsum; Jar = Jarosite; Flu = fluroapitite. Mineral abbreviations after Whitney and Evans (2010); Si-rich Sh = silica rich shale; Ca-rich Sh = calcite rich shale.

\section{Appendix B}

Table A2. Relative clay mineral abundances determined by Sybilla modeling of analyzed samples from the Midland Basin.

\begin{tabular}{|c|c|c|c|c|c|c|c|c|c|c|}
\hline Sample & Depth (m) & Lithofacies & Ill & R0 I-S & R0 I-SS & R0 I-SSS & R1 I-S & R3 I-S & Chl & R0 C-SS \\
\hline T401-7620 & 2322.6 & Si-rich Sh & 7.3 & 31.9 & 19.0 & 41.7 & 0.0 & 0.0 & 0.0 & 0.0 \\
\hline T401-7627 & 2324.7 & Ca-rich Sh & 7.5 & 82.5 & 0.0 & 10.0 & 0.0 & 0.0 & 0.0 & 0.0 \\
\hline T401-7657 & 2333.9 & Limestone & 3.6 & 27.8 & 68.6 & 0.0 & 0.0 & 0.0 & 0.0 & 0.0 \\
\hline T401-7665 & 2336.3 & Si-rich Sh & 2.8 & 53.3 & 43.9 & 0.0 & 0.0 & 0.0 & 0.0 & 0.0 \\
\hline T401-7669 & 2337.5 & Dolomite & 4.0 & 56.4 & 39.6 & 0.0 & 0.0 & 0.0 & 0.0 & 0.0 \\
\hline T401-7673 & 2338.7 & Si-rich Sh & 20.3 & 40.4 & 37.9 & 0.0 & 0.0 & 0.0 & 1.4 & 0.0 \\
\hline T401-7718 & 2352.4 & Si-rich Sh & 15.4 & 82.1 & 0.0 & 0.0 & 0.0 & 0.0 & 2.5 & 0.0 \\
\hline T401-7741 & 2359.5 & Si-rich Sh & 7.9 & 55.7 & 28.9 & 0.0 & 0.0 & 0.0 & 2.8 & 4.7 \\
\hline T401-8156 & 2485.9 & Si-rich Sh & 24.8 & 0.0 & 25.8 & 0.0 & 45.2 & 0.0 & 0.9 & 3.4 \\
\hline T401-8167 & 2489.3 & Si-rich Sh & 32.5 & 0.0 & 0.0 & 0.0 & 62.8 & 0.0 & 1.5 & 3.3 \\
\hline T401-8175 & 2491.7 & Si-rich Sh & 19.8 & 0.0 & 10.0 & 0.0 & 65.7 & 0.0 & 1.2 & 3.3 \\
\hline T401-8197 & 2498.4 & Si-rich Sh & 21.9 & 0.0 & 0.0 & 0.0 & 73.9 & 0.0 & 3.4 & 0.9 \\
\hline T401-8217 & 2504.5 & Si-rich Sh & 19.8 & 0.0 & 0.0 & 0.0 & 75.9 & 0.0 & 2.6 & 1.7 \\
\hline T401-8252 & 2515.2 & Si-rich Sh & 16.0 & 0.0 & 0.0 & 0.0 & 79.9 & 0.0 & 4.1 & 0.0 \\
\hline T401-8256 & 2516.4 & Si-rich Sh & 21.4 & 0.0 & 0.0 & 0.0 & 73.8 & 0.0 & 4.8 & 0.0 \\
\hline
\end{tabular}


Table A2. Cont.

\begin{tabular}{|c|c|c|c|c|c|c|c|c|c|c|}
\hline Sample & Depth (m) & Lithofacies & Ill & R0 I-S & R0 I-SS & R0 I-SSS & R1 I-S & R3 I-S & Chl & R0 C-SS \\
\hline T901-9004 & 2744.4 & Si-rich Sh & 7.3 & 0.0 & 50.7 & 0.0 & 0.0 & 21.4 & 3.2 & 17.4 \\
\hline T901-9005 & 2744.7 & Si-rich Sh & 2.6 & 0.0 & 0.0 & 0.0 & 48.0 & 38.4 & 0.0 & 11.0 \\
\hline T901-9015 & 2747.8 & Si-rich Sh & 41.3 & 0.0 & 16.9 & 0.0 & 0.0 & 41.8 & 0.0 & 0.0 \\
\hline T901-9027 & 2751.4 & Ca-rich Sh & 2.6 & 0.0 & 0.0 & 0.0 & 0.0 & 92.4 & 2.3 & 2.6 \\
\hline T901-9033 & 2753.3 & Si-rich Sh & 0.0 & 0.0 & 69.7 & 0.0 & 0.0 & 30.3 & 0.0 & 0.0 \\
\hline JP-11091 & 3380.5 & Ca-rich Sh & 16.7 & 37.5 & 0.0 & 0.0 & 40.7 & 0.0 & 5.0 & 0.0 \\
\hline JP-11107 & 3385.4 & Ca-rich Sh & 18.8 & 18.7 & 0.0 & 0.0 & 57.0 & 0.0 & 5.5 & 0.0 \\
\hline JP-11118 & 3388.8 & Si-rich Sh & 27.1 & 0.0 & 0.0 & 0.0 & 63.8 & 0.0 & 2.7 & 6.4 \\
\hline JP-11135 & 3393.9 & Si-rich Sh & 8.4 & 0.0 & 30.5 & 0.0 & 58.3 & 0.0 & 1.1 & 1.7 \\
\hline
\end{tabular}

Abbreviations: Ill—illite; I-S, I-SS, and I-SSS—mixed-layered illite-smectite, illite-smectite-smectite, illite-smectite-smectite-smectite; Chl—chlorite; C-SS—chlorite-smectite-smectite;

R-Reichweit (measure of order); Mineral abbreviations after Kretz (1983) and Whitney and Evans (2010).

\section{Appendix C}

Table A3. Sybilla ${ }^{\circledR}$ parameters of main phyllosilicates and mixed-layered phases used for XRD spectra modelling of representative clay fraction samples.

\begin{tabular}{|c|c|c|c|c|c|c|c|}
\hline Phase/Mixed-layer Phase & Sample & $\sigma^{*}$ & CSDS & Ill (\%) & $\mathrm{Ch}(\%)$ & $\mathrm{Fe}^{\mathrm{IV}}$ & ICC \\
\hline \multirow[t]{14}{*}{ Illite/Muscovite } & T401-7620 & 12.00 & 21.67 & - & - & 1.52 & 1.50 \\
\hline & $\mathrm{T} 401-7627$ & 19.94 & 27.91 & - & - & 1.04 & 1.50 \\
\hline & $\mathrm{T} 401-7657$ & 12.00 & 27.91 & - & - & 0.50 & 1.50 \\
\hline & $\mathrm{T} 401-7665$ & 12.00 & 28.30 & - & - & 0.50 & 1.50 \\
\hline & $\mathrm{T} 401-7669$ & 7.46 & 18.16 & - & - & 1.00 & 1.50 \\
\hline & $\mathrm{T} 401-7673$ & 12.00 & 20.00 & - & - & 0.50 & 1.00 \\
\hline & $\mathrm{T} 401-7718$ & 12.00 & 20.11 & - & - & 0.52 & 1.50 \\
\hline & $\mathrm{T} 401-7741$ & 12.00 & 24.79 & - & - & 2.00 & 1.81 \\
\hline & $\mathrm{T} 401-8156$ & 12.00 & 18.55 & - & - & 0.52 & 1.50 \\
\hline & $\mathrm{T} 401-8167$ & 12.00 & 16.60 & - & - & 0.24 & 1.50 \\
\hline & T401-8175 & 12.00 & 19.72 & - & - & 0.44 & 1.56 \\
\hline & T401-8197 & 12.00 & 20.00 & - & - & 0.50 & 1.50 \\
\hline & $\mathrm{T} 401-8217$ & 12.00 & 20.00 & - & - & 0.50 & 1.50 \\
\hline & T401-8252 & 12.00 & 18.55 & - & - & 0.72 & 1.50 \\
\hline
\end{tabular}


Table A3. Cont.

\begin{tabular}{|c|c|c|c|c|c|c|c|}
\hline Phase/Mixed-layer Phase & Sample & $\sigma^{*}$ & CSDS & Ill (\%) & Ch $(\%)$ & $\mathrm{Fe}^{\mathrm{IV}}$ & ICC \\
\hline & T401-8256 & 12.00 & 20.00 & - & - & 0.08 & 1.50 \\
\hline & T901-9004 & 12.00 & 18.16 & - & - & 0.52 & 1.50 \\
\hline & T901-9005 & 12.00 & 29.08 & - & - & 0.52 & 1.50 \\
\hline & T901-9015 & 12.00 & 4.51 & - & - & 0.20 & 1.50 \\
\hline & T901-9027 & 12.00 & 22.06 & - & - & 1.84 & 1.50 \\
\hline & JP-11091 & 12.00 & 20.00 & - & - & 0.50 & 1.50 \\
\hline & JP-11107 & 12.00 & 20.00 & - & - & 0.50 & 1.50 \\
\hline & JP-11118 & 12.00 & 13.87 & - & - & 0.08 & 1.50 \\
\hline & JP-11135 & 12.00 & 20.00 & - & - & 0.28 & 1.50 \\
\hline \multirow[t]{10}{*}{ R0 I-S } & T401-7620 & 12.00 & 16.08 & 90.00 & - & 1.96 & 1.50 \\
\hline & $\mathrm{T} 401-7627$ & 12.00 & 16.66 & 87.00 & - & 2.20 & 1.50 \\
\hline & T401-7657 & 12.14 & 22.17 & 90.00 & - & 2.68 & 1.50 \\
\hline & T401-7665 & $13.70-15.26$ & $6.80-19.85$ & $87.00-94.00$ & - & $0.76-2.00$ & 1.50 \\
\hline & T401-7669 & 16.04 & 7.09 & 94.00 & - & 2.12 & 1.50 \\
\hline & T401-7673 & 12.00 & 5.35 & 95.00 & - & 3.00 & 1.50 \\
\hline & T401-7718 & 12.00 & 6.22 & 90.00 & - & 2.00 & 1.50 \\
\hline & T401-7741 & 12.00 & 23.62 & 86.00 & - & 2.88 & 1.50 \\
\hline & JP-11091 & 12.00 & 6.22 & 89.00 & - & 1.56 & 0.96 \\
\hline & JP-11107 & 12.00 & 11.44 & 90.00 & - & 0.50 & 1.00 \\
\hline \multirow[t]{13}{*}{ R0 I-SS } & T401-7620 & 12.00 & 7.38 & 82.00 & - & 0.84 & 1.50 \\
\hline & T401-7627 & 54.26 & 10.86 & 72.00 & - & 0.50 & 1.50 \\
\hline & T401-7657 & 12.00 & $8.25-12.02$ & $73.00-90.00$ & - & $0.64-1.16$ & 1.50 \\
\hline & T401-7665 & $13.70-16.04$ & $6.22-20.43$ & $80.00-81.00$ & - & $0.52-2.52$ & 1.50 \\
\hline & T401-7669 & $12.00-16.82$ & $15.50-15.79$ & $65.00-84.00$ & - & 0.50 & 1.50 \\
\hline & T401-7673 & 12.00 & 6.22 & 70.00 & - & 0.50 & 1.50 \\
\hline & $\mathrm{T} 401-7741$ & 12.00 & 12.02 & 80.00 & - & 0.50 & 1.50 \\
\hline & T401-8156 & 9.02 & 6.22 & 80.00 & - & 1.60 & 1.50 \\
\hline & T401-8175 & 12.00 & 3.32 & 62.00 & - & 0.50 & 1.50 \\
\hline & T901-9004 & 12.00 & 4.77 & 83.00 & - & 3.08 & 1.50 \\
\hline & T901-9015 & 15.26 & 14.05 & 10.00 & - & 1.00 & 1.50 \\
\hline & T901-9033 & 12.00 & 24.20 & 75.00 & - & 0.84 & 1.50 \\
\hline & JP-11135 & 12.00 & 8.25 & 69.00 & - & 3.00 & 1.51 \\
\hline
\end{tabular}


Table A3. Cont.

\begin{tabular}{|c|c|c|c|c|c|c|c|}
\hline Phase/Mixed-layer Phase & Sample & $\sigma^{*}$ & CSDS & Ill (\%) & Ch (\%) & $\mathrm{Fe}^{\mathrm{IV}}$ & ICC \\
\hline \multirow[t]{2}{*}{ R0 I-SSS } & T401-7620 & 12.00 & 4.48 & 87.00 & - & 0.50 & 1.50 \\
\hline & $\mathrm{T} 401-7627$ & 12.00 & $1.29-2.74$ & $11.00-53.00$ & - & 0.50 & 1.50 \\
\hline \multirow[t]{12}{*}{ R1 I-S } & $\mathrm{T} 401-8156$ & 10.58 & 5.64 & 95.00 & - & 1.88 & 1.50 \\
\hline & $\mathrm{T} 401-8167$ & 10.58 & 4.77 & 95.00 & - & 1.88 & 1.51 \\
\hline & $\mathrm{T} 401-8175$ & 12.00 & 5.64 & 90.00 & - & 1.20 & 1.50 \\
\hline & $\mathrm{T} 401-8197$ & 12.00 & 5.93 & 89.00 & - & 1.88 & 1.50 \\
\hline & $\mathrm{T} 401-8217$ & 12.00 & 6.51 & 87.00 & - & 2.00 & 1.50 \\
\hline & $\mathrm{T} 401-8252$ & 12.00 & 5.64 & 84.00 & - & 1.52 & 1.50 \\
\hline & $\mathrm{T} 401-8256$ & 12.00 & 5.64 & 90.00 & - & 2.56 & 1.50 \\
\hline & T401-9005 & 12.00 & 4.19 & 88.00 & - & 0.52 & 1.50 \\
\hline & JP-11091 & 12.00 & 13.18 & 75.00 & - & 1.80 & 1.50 \\
\hline & JP-11107 & 12.00 & 3.61 & 90.00 & - & 2.72 & 1.29 \\
\hline & JP-11118 & 12.00 & 11.15 & 77.00 & - & 3.80 & 1.50 \\
\hline & JP-11135 & 12.00 & 7.09 & 93.00 & - & 1.88 & 1.50 \\
\hline \multirow[t]{15}{*}{ Chlorite } & T401-7673 & 12.00 & 20.00 & - & - & 1.80 & 1.00 \\
\hline & T401-7718 & 12.00 & 14.65 & - & - & 1.72 & 1.00 \\
\hline & T401-7741 & 12.00 & 15.04 & - & - & 1.00 & 1.08 \\
\hline & T401-8156 & 12.00 & 27.13 & - & - & 1.96 & 1.98 \\
\hline & T401-8167 & 12.00 & 22.06 & - & - & 1.44 & 1.02 \\
\hline & T401-8175 & 12.00 & 20.00 & - & - & 2.20 & 1.00 \\
\hline & T401-8197 & 12.00 & 15.43 & - & - & 2.00 & 1.98 \\
\hline & T401-8217 & 12.00 & 17.38 & - & - & 2.00 & 1.00 \\
\hline & $\mathrm{T} 401-8252$ & 12.00 & 13.87 & - & - & 2.00 & 1.00 \\
\hline & $\mathrm{T} 401-8252$ & 12.00 & 13.87 & - & - & 2.08 & 1.80 \\
\hline & T901-9004 & 12.00 & 17.77 & - & - & 2.32 & 1.14 \\
\hline & T901-9027 & 12.00 & 11.53 & - & - & 3.00 & 1.02 \\
\hline & JP-11091 & 12.00 & 11.92 & - & - & 2.08 & 1.00 \\
\hline & JP-11107 & 12.00 & 13.09 & - & - & 1.96 & 1.00 \\
\hline & JP-11118 & 12.00 & 14.26 & - & - & 1.84 & 1.98 \\
\hline
\end{tabular}


Table A3. Cont.

\begin{tabular}{|c|c|c|c|c|c|c|c|}
\hline Phase/Mixed-layer Phase & Sample & $\sigma^{*}$ & CSDS & Ill (\%) & $\mathrm{Ch}(\%)$ & $\mathrm{Fe}^{\mathrm{IV}}$ & ICC \\
\hline \multirow[t]{5}{*}{ R0 Di C-SS } & T401-7741 & 12.00 & 10.86 & - & 59.00 & 0.50 & 1.00 \\
\hline & T401-8197 & 12.00 & 5.64 & - & 37.00 & 0.50 & 1.00 \\
\hline & $\mathrm{T} 401-8217$ & 12.00 & 5.64 & - & 38.00 & 0.50 & 1.00 \\
\hline & T901-9005 & 12.00 & 8.54 & - & 25.00 & 3.32 & 2.04 \\
\hline & JP-11118 & 12.00 & 13.18 & - & 76.00 & 1.44 & 2.04 \\
\hline \multirow[t]{6}{*}{ R0 Tri C-SS } & $\mathrm{T} 401-8156$ & 12.00 & 19.27 & - & 83.00 & 2.80 & 4.56 \\
\hline & $\mathrm{T} 401-8167$ & 12.00 & 9.99 & - & 81.00 & 2.88 & 4.92 \\
\hline & T401-8175 & 12.00 & 3.90 & - & 36.00 & 2.00 & 1.00 \\
\hline & T901-9004 & 12.00 & 5.35 & - & 68.00 & 1.36 & 1.98 \\
\hline & T901-9027 & 12.00 & 3.03 & - & 50.00 & 0.50 & 1.00 \\
\hline & JP-11135 & 12.00 & 6.51 & - & 85.00 & 1.76 & 1.02 \\
\hline
\end{tabular}

Abbreviations: $\sigma^{*}$ —orientation of particles on the mounted X-ray slide; CSDS—coherent scattering domain sizes expressed in layers; Ill (\%), Chl (\%)—illite component, and chlorite component in the respective mixed-layered minerals (in \%); I-S, I-SS, I-SSS, Di-SS, Di C-SS, and Tri C-SS-mixed-layered illite-smectite, illite-smectite-smectite, illite-smectite-smectite-smectite, dioctahedral smectite, dioctahedral chlorite-smectite-smectite, and trioctahedral chlorite-smectite-smectite; $\mathrm{R}$-Reichweit (measure of order); Fe ${ }^{\mathrm{VI}}$-octahedral Fe in illite (I), and chlorite (C); ICC-interlayer cation content in illite (Ill) and chlorite (Chl) 


\section{References}

1. Tissot, B.; Welte, D.H. Petroleum Formation and Occurrence, 2nd ed.; Springer: Berlin, Germany, 1984.

2. Hunt, J.M. Petroleum Geochemistry and Geology, 2nd ed.; W.H. Freeman and Company: New York, NY, USA, 1996.

3. Killops, S.; Killops, V. Introduction to Organic Geochemistry, 2nd ed.; Blackwell Publishing: Malden, MA, USA, 2005.

4. Gouze, P.; Coudrain-Ribstein, A. Chemical reactions and porosity changes during sedimentary diagenesis. Appl. Geochem. 2002, 17, 39-47. [CrossRef]

5. Aplin, A.C.; Macquaker, J.H.S. Mudstone diversity: Origin and implications for source, seal, and reservoir properties in petroleum systems. AAPG Bull. 2011, 95, 2031-2059. [CrossRef]

6. Ilgen, A.G.; Heath, J.E.; Akkutlu, I.Y.; Bryndzia, L.T. Shales at all scales: Exploring coupled processes in mudrocks. Earth Sci. Rev. 2017, 166, 132-152. [CrossRef]

7. Sayed, M.A.; Al-Muntasheri, G.A.; Liang, F. Development of shales reservoirs: Knowledge gained from developments in North America. J. Pet. Sci. Eng. 2017, 157, 164-186. [CrossRef]

8. Rahman, H.M.; Kennedy, M.; Lohr, S.; Dewhurst, D.N. Clay-organic association as a control on hydrocarbon generation in shale. Org. Geochem. 2017, 105, 42-55. [CrossRef]

9. Rahman, H.M.; Kennedy, M.; Lohr, S.; Dewhurst, D.N. The influence of shale depositional fabric on the kinetics of hydrocarbon generation through control of mineral surface contact area on clay catalysis. Geochim. Cosmochim. Acta 2018, 220, 429-448. [CrossRef]

10. Hillier, S. Origin, diagenesis, and mineralogy of chlorite minerals in Devonian lacustrine mudrocks, Orcadian basin, Scotland. Clays Clay Miner. 1993, 41, 240-259. [CrossRef]

11. Pevear, D.R. Illite and hydrocarbon exploration. Proc. Natl. Acad. Sci. USA 1999, 96, 3440-3446. [CrossRef] [PubMed]

12. Środon, J. Nature of mixed-layer clays and mechanisms of their formation and alteration. Annu. Rev. Earth Planet. Sci. 1999, 27, 19-53. [CrossRef]

13. Dellisanti, F.; Pini, G.A.; Baudin, F. Use of Tmax as a thermal indicator in organic successions and comparison with clay mineral evolution. Clay Miner. 2010, 45, 115-130. [CrossRef]

14. Tissot, B.P.; Pelet, R.; Ungerer, P.H. Thermal History of Sedimentary Basins, Maturation Indices, and Kinetics of Oil and Gas Generation. AAPG Bull. 1987, 71, 1445-1466. [CrossRef]

15. Landis, C.R.; Castano, J.R. Maturation and bulk chemical properties of a suite of solid hydrocarbons. Org. Geochem. 1995, 22, 137-149. [CrossRef]

16. Rimmer, S.M.; Thompson, J.A.; Goodnight, S.A.; Robl, T.L. Multiple controls on the preservation of organic matter in Devonian-Mississippian marine black shales: Geochemical and petrographic evidence. Paleogeogr. Paleoclimatol. Paleoecol. 2004, 215, 125-154. [CrossRef]

17. Bernard, S.; Wirth, R.; Schreiber, A.; Schulz, H.M.; Horsfield, B. Formation of nanoporous pyrobitumen residues during maturation of the Barnett Shale (Fort Worth Basin). Int. J. Coal Geol. 2012, 103, 3-11. [CrossRef]

18. Curiale, J.A.; Curtis, J.B. Organic geochemical applications to the exploration for source-rock reservoirs-A review. J. Unconv. Oil Gas. Resour. 2016, 13, 1-31. [CrossRef]

19. Pollastro, R.M.; Barker, C. Applications of clay-mineral, vitrinite reflectance, and fluid inclusion studies to the thermal and burial history of the Pindale Anticline, Green River Basin, Wyoming. In Organic Matter in Sediment Diagenesis; Gautier, D.L., Ed.; Society of Economic Paleontologists and Mineralogists Special Publication 38; Society for Sedimentary Geology: Tulsa, OK, USA, 1986; pp. 73-83.

20. Ferreiro Mählmann, R.; Bozkaya, Ö.; Potel, S.; Bayon, R.L.; Šegvić, B.; Nieto, F. The pioneer work of Bernard Kübler and Martin Frey in very low-grade metamorphic terranes: Paleo-geothermal potential of variation in Kübler-Index/organic matter reflectance correlations. A review. Swiss J. Geosci. 2012, 105, 121-152. [CrossRef]

21. Ola, P.S.; Aidi, A.K.; Bankole, O.M. Clay mineral diagenesis and source rock assessment in the Bornu Basin, Nigeria: Implications for the thermal maturity and source rock potential. Mar. Pet. Geol. 2018, 89, 653-664. [CrossRef] 
22. Wust, R.A.J.; Hackley, P.C.; Nassichuk, B.R. Vitrinite reflectance versus pyrolysis Tmax Data: Assessing thermal maturity in shale plays with special reference to the Duvernay shale play of the western Canadian sedimentary basin, Alberta, Canada. In Proceedings of the SPE Unconventional Resources Conference and Exhibition-Asia Pacific, Brisbane, Australia, 11-13 November 2013. SPE 167031.

23. Hackley, P.C.; Guevara, E.H.; Hentz, T.F.; Hook, R.W. Thermal maturity and organic composition of Pennsylvanian coals and carbonaceous shales, north-central Texas: Implications of coalbed gas potential. Int. J. Coal Geol. 2009, 77, 294-309. [CrossRef]

24. Merriman, R. Clay minerals and sedimentary basin history. Eur. J. Mineral. 2005, 17, 7-20. [CrossRef]

25. Peters, K.E. Guidelines for Evaluating Petroleum Source Rock Using Programmed Pyrolysis. AAPG Bull. 1986, 70, 318-329. [CrossRef]

26. Baludikay, B.K.; Francois, C.; Sforna, M.C.; Beghin, J.; Cornet, Y.; Strome, J.; Fagel, N.; Fontaine, F.; Littke, R.; Baudet, D.; et al. Raman microspectroscopy, bitumen reflectance and illite crystallinity scale: Comparison of different geothermetry methods on fossiliferous Proterozoic sedimentary basins (DR Congo, Mauritania and Australia). Int. J. Coal Geol. 2018, 191, 80-94. [CrossRef]

27. Tobin, R.C.; Claxton, B.L. Multidisciplinary thermal maturity studies using vitrinite reflectance and fluid inclusion mirothermometry: A new calibration of old techniques. AAPG Bull. 2000, 84, 1647-1665. [CrossRef]

28. Suarez-Ruiz, I.; Flores, D.; Graciano, J.G.M.; Hackley, P.C. Review and update of the applications of organic petrology: Part 1. Int. J. Coal Geol. 2012, 99, 54-112. [CrossRef]

29. Hackley, P.C.; Cardott, B.J. Application of organic petrography in North American shale petroleum systems: A review. Int. J. Coal Geol. 2016, 163, 8-51. [CrossRef]

30. Hackley, P.C.; Zhang, T.; Jubb, A.M.; Valentine, B.J.; Dulong, F.T.; Hatcherian, J.J. Organic petrography of Leonardian (Wolfcamp A) mudrocks and carbonates, Midland Basin, Texas: The fate of oil-prone sedimentary organic matter in the oil window. Mar. Pet. Geol. 2020, 112, 104086. [CrossRef]

31. Hackley, P.C.; Araujo, C.V.; Borrego, A.G.; Bouzinos, A.; Cardott, B.; Cook, A.C.; Eble, C.; Flores, D.; Gentzis, T.; Gonçalves, P.A.; et al. Standardization of reflectance measurements in dispersed organic matter: Results of an exercise to improve interlaboratory agreement. Mar. Pet. Geol. 2015, 59, 22-34. [CrossRef]

32. Jarvie, D.M.; Claxton, B.L.; Henk, F.; Breyer, J.T. Oil and Shale Gas from the Barnett Shale, Ft. Worth Basin, Texas. In Proceedings of the AAPG National Convention, Denver, CO, USA, 3-6 June 2001.

33. Matava, T.; Matt, V.; Flannery, J. New insights on measured and calculated vitrinite reflectance. Basin Res. 2019, 31, 213-227. [CrossRef]

34. Caritat, P.; Hutcheon, I.; Walshe, J.L. Chlorite geothermometry: A review. Clays Clay Miner. 1993, 41, $219-239$. [CrossRef]

35. Pollastro, R.M. Considerations and applications of the illite/smectite geothermometer in hydrocarbon-bearing rocks of Miocene to Mississippian Age. Clays Clay Miner. 1993, 41, 119-133. [CrossRef]

36. Beaufort, D.; Rigault, C.; Billon, S.; Billault, V.; Inoue, A.; Inoue, S.; Patrier, P. Chlorite and chloritization processes through mixed-layer mineral series in low-temperature geological systems-A review. Clay Miner. 2015, 50, 497-523. [CrossRef]

37. Wilson, M.J.; Shaldybin, M.V.; Wilson, L. Clay mineralogy and unconventional hydrocarbon shale reservoirs in the USA. I. Occurrence and interpretation of mixed-layer R3 ordered illite/smectite. Earth-Sci. Rev. 2016, 158, 31-50. [CrossRef]

38. Zanoni, G.; Šegvić, B.; Moscariello, A. Clay mineral diagenesis in Cretaceous clastic reservoirs from West African passive margins (the South Gabon Basin) and its impact on regional geology and basin evolution history. Appl. Clay Sci. 2016, 134, 186-209. [CrossRef]

39. Perry, E.A.; Hower, J. Burial diagenesis in Gulf Coast pelitic sediments. Clays Clay Miner. 1970, 29 , $165-177$. [CrossRef]

40. Dudek, T.; Środoń, J. Thickness distribution of illite crystals in shales. II: Origins of the distribution and the mechanism of smectte illiization in shales. Clay Clay Miner. 2003, 51, 529-542. [CrossRef]

41. Energy Information Administration (EIA). Permian Basin Wolfcamp and Bone Spring Shale Plays: Geology Review. Available online: https://www.eia.gov/maps/pdf/Wolfcamp_BoneSpring_EIA_Report_July2019.pdf (accessed on 23 June 2020).

42. Kvale, E.P.; Rahman, M. Depositional facies and organic content of upper Wolfcamp Formation (Permian) Delaware Basin and implications for sequence stratigraphy and hydrocarbon source. In Proceedings of the Unconventional Resources Technology Conference (URTeC), San Antonio, TX, USA, 1-3 August 2016. 
43. Lewan, M.D.; Pawlewicz, M.J. Reevalutaion of thermal maturity and stages of petroleum formation of the Mississippian Barnett Shale, Fort Worth Basin, Texas. AAPG Bull. 2017, 101, 1945-1970. [CrossRef]

44. MacRitchie, C.; Zobaa, M.K. Multiproxy sedimentary organic matter analysis of the upper Wolfcamp Formation in the Collier-1201 well, southeastern Delaware Basin, Texas. Interpretation 2019, 7, SK45-SK52. [CrossRef]

45. Landis, C.R. Organic Maturation, Primary Migration, and Clay Mineralogy of Selected Permian Basin Shales. Ph.D. Thesis, Texas Tech University, Lubbock, TX, USA, 1990.

46. Sivagnanam, S. Clay Diagenesis of the Source Rocks from the Permian Basin. Ph.D. Thesis, Texas Tech University, Lubbock, TX, USA, 1990.

47. Echegu, S. Geological and Geochemical Investigation of the Petroleum Systems of the Permian Basin of west Texas and southeast New Mexico. Ph.D. Thesis, University of Houston, Houston, TX, USA, 2013.

48. Hills, J.M. Sedimentation, tectonism, and hydrocarbon generation in the Delaware Basin, west Texas and southeastern New Mexico. AAPG Bull. 1984, 68, 250-267.

49. Candelaria, M.P. “Atoka” detrital a subtle stratigraphic trap in the Midland Basin. In Permian Basin Oil and Gas Fields; Innovative Ideas in Exploration and Development; Flis, J.E., Price, R.C., Eds.; West Texas Geological Society: Midland, TX, USA, 1990; pp. 87-90.

50. Comer, J.B. Stratigraphic Analysis of the upper Devonian Woodford Formation, Permian Basin, West Texas and Southeastern New Mexico; Bureau of Economic Geology: Austin, TX, USA, 1991; Report of Investigation 201.

51. Horak, R.L. Tectonic and hydrocarbon maturation history in the Permian Basin. Oil Gas. J. 1985, 27, $124-129$.

52. Yang, K.M.; Dorobek, S.L. The Permian Basin of west Texas and New Mexico: Tectonic history of a "composite" foreland basin and its effects on stratigraphic development. In Stratigraphic Evolution of Foreland Basins; Dorobek, S.L., Ross, G.M., Eds.; Society for Sedimentary Geology: Tulsa, OK, USA, 1995; pp. 149-174.

53. Ye, H.; Royden, L.; Burchfield, C.; Schuepbach, M. Late Paleozoic deformation of interior North America: The greater Ancestral Rocky Mountains. AAPG Bull. 1996, 80, 1397-1432. [CrossRef]

54. Helm, J.M. The Depositional Environment and Thermal Maturity of the upper Wolfcamp Formation in Crockett County, TX, MS; University of Louisiana at Lafayette: Lafayette, LA, USA, 2015.

55. Schumaker, R.C. Paleozoic structure of the Central Basin Uplift and adjacent Delaware Basin, West Texas. AAPG Bull. 1992, 76, 1804-1824. [CrossRef]

56. Ewing, T.E. Texas through Time: Lone Star Geology, Landscapes, and Resources; Bureau of Economic Geology, Udden Series No. 6: Austin, TX, USA, 2016.

57. Kinley, T.J.; Cook, L.W.; Breyer, J.A.; Jarive, D.M.; Busbey, A.B. Hydrocarbon potential of the Barnett Shale (Mississippian), Delaware Basin, west Texas and southeastern New Mexico. AAPG Bull. 2008, 92, 967-991. [CrossRef]

58. Hills, J.M. Structural evolution of the Permian Basin of west Texas and New Mexico. In Structure and Tectonics of Trans-Pecos Texas; Dickerson, P.W., Muehlberger, W.R., Eds.; West Texas Geological Society Guidebook: Midland, TX, USA, 1985; pp. 89-99.

59. Frenzel, H.N.; Bloomer, R.R.; Cline, R.B.; Cys, J.M.; Galley, J.E.; Gibson, W.R.; Hills, J.M.; King, W.E.; Seager, W.R.; Kottlowski, R.E.; et al. The Permian Basin region. In The Geology of North America Sedimentary Cover-North American Craton: U.S.; Sloss, L.L., Ed.; Geological Society of America: Boulder, CO, USA, 1988; Volume D-2, pp. 261-306.

60. Wright, W.R. Pennsylvanian paleodepositional evolution of the greater Permian Basin, Texas and New Mexico: Depositional systems and hydrocarbon reservoir analysis. AAPG Bull. 2011, 95, 1525-1555. [CrossRef]

61. Alnazghah, M.; Kerans, C. Late Pennsylvanian glaciation: Evidence of icehouse conditions from Canyon and Cisco units, Midland Basin, Texas. Mar. Pet. Geol. 2018, 94, 198-211. [CrossRef]

62. Kohn, J.; Barrick, J.E.; Wahlman, G.P.; Baumgardner, R. Late Pennsylvanian (Virgilian) to Early Permian (Leonardian) conodont biostratigraphy of the "Wolfcamp Shale," northern Midland Basin, Texas. In Geologic Problem Solving with Microfossils IV; Society for Sedimentary Geology: Tulsa, OK, USA, 2019; pp. 245-261.

63. Handford, C.R. Deep-water facies of the Spraberry Formation (Permian), Regan County, Texas. In Deep-Water Clastic Sediments; Siemers, C.T., Tillman, R.W., Williamson, C.R., Eds.; Society for Sedimentary Geology: Tulsa, OK, USA, 1981; pp. 375-395.

64. Brister, B.S.; Stephens, W.C.; Norman, G.A. Structure, stratigraphy, and hydrocarbon system of Pennsylvanian pull-apart basin in north-central Texas. AAPG Bull. 2002, 86, 1-20. 
65. Yang, W.; Kominz, M.A. Characteristics, stratigraphic architecture, and time framework of multi-order mixed siliciclastic and carbonate depositional sequence, outcropping Cisco Group (Late Pennsylvanian and Early Permian, Eastern Shelf, north-central Texas, USA. Sediment. Geol. 2002, 154, 53-87. [CrossRef]

66. Mazzullo, S.J.; Reid, A.M. Lower Permian platform and basin depositional systems, northern Midland Basin, Texas. In Controls on Carbonate Platforms and Basin Development; Crevello, P.D., Wilson, J.L., Sarg, J.F., Read, J.F., Eds.; Society for Sedimentary Geology: Tulsa, OK, USA, 1989; pp. 305-320.

67. Hamlin, H.S.; Baumgardner, R.W. Wolfberry (Wolfcampian-Leonardian) Deep-Water Depositional Systems in the Midland Basin Stratigraphy, Lithofacies, Reservoirs, and Source Rocks; Bureau of Economic Geology: Austin, TX, USA, 2012; Report of Investigations 277.

68. Heij, G.W.; Elmore, R.D. The magnetic fabric of the Wolfcamp shale, Midland Basin, west Texas: Understanding petrofabric variability, hydrocarbon associations, and iron enrichment. AAPG Bull. 2019, 103, 2785-2806. [CrossRef]

69. Ewing, T.E. Erosional margins and patterns of subsidence in the late Paleozoic west Texas basin and adjoining basins of west Texas and New Mexico. In Carlsbad Region (New Mexico and West Texas), Proceedings of the New Mexico Geological Society 44th Annual Fall Field Conference Guidebook, Carlsbad, CA, USA, 6-9 October 1993; Love, D.W., Hawley, J.W., Kues, B.S., Austin, G.S., Lucas, S.G., Eds.; NM Bureau of Geology \& Mineral Resources (NMBGMR): Socorro, NM, USA, 1993.

70. Leslie, C.; Waite, L.; Ndungu, J.; Johnson, E.; Foster, D.; Maymi, N.; O'Connell, L.; Edmonds, J. Occurrence of volcanic ash beds in the Wolfcamp and Spraberry of the Midland Basin and their potential challenges to drilling. In Proceedings of the AAPG Southwest Section Meeting, Dallas, TX, USA, 6-9 April 2019. Search and Discovery Article \#51637.

71. Heij, G.W.; Elmore, R.D. Burial diagenesis and tectonism inferred from paleomagnetism and magnetic fabrics in the Wolfcamp Shale, Midland Basin, TX, USA. J. Geophys. Res. Solid Earth 2020, 125, e2019JB019046. [CrossRef]

72. Lazar, O.R.; Bohacs, K.M.; MacQuaker, J.H.S.; Schieber, J.; Demko, T. Capturing key attributes of fine-grained sedimentary rocks in outcrops, cores, and thin sections: Nomenclature and description guidelines. J. Sediment. Res. 2015, 85, 230-246. [CrossRef]

73. Moore, D.M.; Reynolds, R.C. X-ray Diffraction and the Identification and Analysis of Clay Minerals, 2nd ed.; Oxford University Press: Oxford, UK, 1997.

74. Środoń, J. Identification and quantitative analysis of clay minerals. In Handbook of Clay Science; Bergaya, F., Theng, B.K.G., Lagaly, G., Eds.; Developments in Clay Science, Elsevier: Amsterdam, Netherlands, 2006.

75. Lagaly, G.; Ogawa, M.; Dékány, I. Clay mineral organic interactions. In Handbook of Clay Science; Bergaya, F., Theng, B.K.G., Lagaly, G., Eds.; Developments in Clay Science, Elsevier: Amsterdam, Netherlands, 2006.

76. Meunier, A. Soil hydroxy-interlayered minerals: A reinterpretation of their crystallochemical properties. Clays Clay Miner. 2007, 55, 380-388. [CrossRef]

77. Drits, V.A.; Sakharov, B.A. X-ray Structural Analysis of Mixed-Layer Minerals; Nauka: Moscow, Russia, 1976.

78. Uzarowicz, Ł.; Šegvić, B.; Michalik, M.; Bylina, P. The effect of hydrochemical conditions and pH of the environment on phyllosilicate transformations in the weathering zone of pyrite-bearing schists in Wieściszowice (SW Poland). Clay Miner. 2012, 47, 401-417. [CrossRef]

79. Suquet, H.; De la Calle, C.; Pezerat, H. Swelling and structural organization of saponite. Clays Clay Miner. 1975, 23, 1-9. [CrossRef]

80. Ferrage, E.; Lanson, B.; Sakharov, B.A.; Drits, V.A. Investigation of smectite hydration properties by modeling of X-ray diffraction profiles. Part 1. Montmorillonite hydration properties. Am. Mineral. 2005, 90, 1358-1374. [CrossRef]

81. Zhou, X.; Liu, D.; Bu, H.; Deng, L.; Liu, H.; Yuan, P.; Du, P.; Song, H. XRD-based quantitative analysis of clay minerals using reference intensity ratios, mineral intensity factors, Rietveld, and full pattern summation methods: A critical review. Solid Earth Sci. 2018, 3, 16-29. [CrossRef]

82. Ordonez, L.; Vogel, H.; Sebag, D.; Ariztegui, D.; Adatte, T.; Russell, J.M.; Kallmeyer, J.; Vuillemin, A.; Friese, A.; Crowe, S.A.; et al. Empowering conventional Rock-Eval pyrolysis for organic matter characterization of the siderite-rich sediments of Lake Towuti (Indonesia) using End-Member Analysis. Org. Geochem. 2019, 134, 32-44. [CrossRef]

83. Hower, J. Shale diagenesis. In Clays and the Resource Geologist; Longstaffe, F.J., Ed.; Smithsonian Libraries: Washington, DC, USA, 1981; pp. 60-80. 
84. Jarvie, D.M. Correlation of Tmax and Measured Vitrinite Reflectance. Available online: http://www.wildcattechnologies.com/application/files/9915/1689/1979/Dan_Jarvie_Correlation_of_ Tmax_and_measured_vitrinite_reflectance.pdf (accessed on 15 July 2020).

85. Barker, C.E.; Pawlewicz, M.J. Calculation of vitrinite reflectance from thermal histories and peak temperatures. A comparison of methods. In Vitrinite Reflectance as a Maturity Parameter: Applications and Limitations; Mukhopadhyay, P.K., Dow, W.G., Eds.; ACS Publications: Washington, DC, USA, 1994; pp. 216-229.

86. Reynolds, R.C.; Hower, J. The Nature of Interlayering in Mixed-Layer Illite-Montmorillonites. Clays Clay Miner. 1970, 18, 25-36. [CrossRef]

87. Espitalié, J.; Deroo, G.; Marquis, F. La pyrolyse Rock-Eval et ses applications: Première Partie. Oil Gas. Sci. Technol. 1985, 40, 563-580. [CrossRef]

88. Espitalié, J.; Deroo, G.; Marquis, F. La pyrolisis Rock-Eval et ses applications: Deuxième partie. Oil Gas. Sci. Technol. 1985, 40, 755-784.

89. Espitalié, J.; Deroo, G.; Marquis, F. La pyrolyse Rock-Eval et ses applications. Troisième partie. Oil Gas. Sci. Technol. 1986, 41, 73-89. [CrossRef]

90. Peters, K.E. Rock-Eval pyrolysis. In Geochemistry. Encyclopedia of Earth Science; Springer: Dordrecht, Netherlands, 1998.

91. Hower, J.; Eslinger, E.V.; Hower, M.E.; Perry, E.A. Mechanism of burial metamorphism of argillaceous sediment: Mineralogical and chemical evidence. Geol. Soc. Amer. Bull. 1976, 87, 725-737. [CrossRef]

92. McKinley, J.M.; Worden, R.H.; Ruffell, A.H. Smectite in Sandstones: A Review of the Controls on Occurrence and Behaviour During Diagenesis. In Clay Mineral Cements in Sandstones; Worden, R.H., Morad, S., Eds.; Blackwell Publishing Ltd.: Oxford, UK, 2003; pp. 109-128.

93. Gao, Y.; Wang, C.; Liu, Z.; Du, X.; Ibarra, D.E. Diagenetic and Paleoenvironmental Controls on Late Cretaceous Clay Minerals in the Songliao Basin, Northeast China. Clays Clay Miner. 2015, 63, 469-484. [CrossRef]

94. Pollastro, R.M. The Illite/Smectite Geothermometer-Concepts, Methodology, and Application to Basin History and Hydrocarbon Generation. In Applications of Thermal Maturity Studies to Energy Exploration; Society for Sedimentary Geology: Tulsa, OK, USA, 1990; pp. 1-18.

95. Cuadros, J.; Linares, J. Experimental kinetic study of the smectite-to-illite transformation. Geochim. Cosmochim. Acta 1996, 60, 439-453. [CrossRef]

96. Hoffman, J.; Hower, J. Clay mineral assemblages as low grade metamorphic geothermometers: Application to the thrust faulted disturbed belt of Montana. In Aspects of Diagenesis; Scholle, P.A., Schluger, P.S., Eds.; Society for Sedimentary Geology: Tulsa, OK, USA, 1979; pp. 55-79.

97. Hillier, S.; Matyas, J.; Matter, A.; Vasseur, G. Illite/Smectite diagenesis and its variable correlation with vitrinite reflectance in the Pannonian Basin. Clays Clay Miner. 1995, 43, 174-183. [CrossRef]

98. Meunier, A. Clays; Springer: Berlin, Germany, 2005.

99. Środoń, J.; Eberl, D.D. Illite. In Micas; Bailey, S.W., Ed.; Mineralogical Society of America: Chantilly, VA, USA, 1984; pp. 495-544.

100. Jarvie, D.M.; Hill, R.J.; Ruble, T.E.; Pollastro, R.M. Unconventional shale-gas system: The Mississippian Barnett Shale of north-central Texas as one model for thermogenic shale-gas assessment. AAPG Bull. 2007, 91, 475-499. [CrossRef]

101. Barrenechea, J.F.; Rodas, M.; Frey, M.; Alonso-Azcárate, J.; Mas, J.R. Chlorite, corrensite, and chlorite-mica in Late Jurassic fluvio-lacustrine sediments of the Cameros basin of Northeastern Spain. Clays Clay Miner. 2000, 48, 256-265. [CrossRef]

102. Ehrenberg, S.N. Relationship between diagenesis and reservoir quality in sandstones of the Garn Formation, Haltenbanken, Mid-Norwegian Continental Shelf (1). AAPG Bull. 1990, 74, 1538-1558.

103. Aagaard, P.; Jahren, J.; Harstad, A.; Nilsen, O.; Ramm, M. Formation of grain-coating chlorite in sandstones. Laboratory synthesized vs. natural occurrences. Clay Miner. 2000, 35, 261-269. [CrossRef]

104. Worden, R.H.; Morad, S. Clay minerals in sandstones: Controls on formation, distribution and evolution. In Clay Mineral Cements in Sandstones; Worden, R.H., Morad, S., Eds.; Special Publication of the International Association of Sedimentologists, Blackwells: Oxford, UK, 2003; pp. 3-41.

105. Kvale, E.P.; Bowie, C.M.; Flenthrope, C.; Mace, C.; Parrish, J.M.; Price, B.; Anderson, S.; DiMichele, W. Facies variability within a mixed carbonate-siliciclastic sea-floor fan (upper Wolfcamp Formation, Permian, Delaware Basin, New Mexico). AAPG Bull. 2020, 104, 525-563. [CrossRef] 
106. Coombs, D.S.; Whetten, J.T. Composition of Analcime from sedimentary and burial metamorphic rocks. Geol. Soc. Amer. Bull. 1967, 78, 269-282. [CrossRef]

107. Niu, B.; Yoshimura, T. Smectite Conversion in Diagenesis and Low Grade Hydrothermal Alteration from Neogene Basaltic Marine Sediments in Niigata Basin, Japan. Clay Sci. 1996, 10, 37-56. [CrossRef]

108. Hints, R.; Kirsimäe, K.; Somelar, P.; Kallaste, T.; Kiipli, T. Chloritization of Late Ordovician K-bentonites from the northern Baltic Palaeobasin-influence from source material or diagenetic environment? Sediment. Geol. 2006, 191, 55-66. [CrossRef]

109. Salda, L.H.D.; Luchi, M.G.L.; de Cingolani, C.A.; Varela, R. Laurentia-Gondwana Collision: The Origin of the Famatinian-Appalachian Orogenic Belt (a Review); Geological Society: London, UK, 1998; pp. 219-234, Special Publications 142.

110. Tollo, R.P.; Bartholomew, M.J.; Hibbard, J.P.; Karabinos, P.M. From Rodinia to Pangea: The Lithotectonic Record of the Appalachian Region; Geological Society of America: Boulder, CO, USA, 2010; Memoir 206.

111. Torres, R.; Ruiz, J.; Patchett, P.J.; Grajales, J.M. Permo-Triassic continental arc in eastern Mexico: Tectonic implications for reconstructions of southern North America. In Mesozoic Sedimentary and Tectonic History of North-Central Mexico; Bartolini, C., Wilson, J.L., Lawton, T.F., Eds.; Geological SocietyAmerica: Boulder, CO, USA, 1999; pp. 191-196.

112. Kirsch, M.; Keppie, J.D.; Murphy, J.B.; Solari, L.A. Permian-Carboniferous arc magmatism and basin evolution along the western margin of Pangea: Geochemical and geochronological evidence from the eastern Acatlán Complex, southern Mexico. Geol. Soc. Amer. Bull. 2012, 124, 1607-1628. [CrossRef]

113. Hartmann, J.; West, A.J.; Renforth, P.; Kohler, P.; De La Rocha, C.L.; Wolf-Gladrow, D.; Dürr, H.H.; Scheffran, J. Enhanced chemical weathering as a geoengineering strategy to reduce atmospheric carbon dioxide, supply nutrients, and mitigate ocean acidification. Rev. Geophys. 2013, 51, 113-149. [CrossRef]

114. Worden, R.H.; Griffiths, J.; Wooldridge, L.J.; Utley, J.E.P.; Lawan, A.Y.; Muhammed, D.D.; Simon, N.; Armitage, P.J. Chlorite in sandstones. Earth-Sci. Rev. 2020, 204, 103105. [CrossRef]

115. Chamley, P.D.H. Terrigenous Supply in the Ocean. In Clay Sedimentology; Springer: Berlin/Heidelberg, Germany, 1989; pp. 163-192.

116. Ortega-Gutierrez, F.; Elias-Herrea, M.; Moran-Zenteno, D.J.; Solari, L.; Weber, B.; Luna-Gonzalez, L. The pre-Mesozoic metamorphic basement of Mexico, 1.5 billion years of crustal evolution. Earth-Sci. Rev. 2018, 183, 2-37. [CrossRef]

117. Peters, K.E.; Cassa, M.R. Applied source rock geochemistry. In The Petroleum System-from Source to Trap; Magoon, L.B., Dow, W.G., Eds.; American Association of Petroleum Geologists: Tulsa, OK, USA, 1994; pp. 93-120.

118. Jarvie, D.M. Shale resource systems for oil and gas: Part 1-Shale-gas resource systems. In Shale Reservoirs-Giant Resources for the 21st Century; Breyer, J.A., Ed.; American Association of Petroleum Geologists: Tulsa, OK, USA, 2012; pp. 69-87.

119. Baumgardner, R.W.; Hamlin, H.S. Core-based geochemical study of mudrocks in basinal lithofacies in the Wolfberry play, Midland Basin, Texas, Part II. In Proceedings of the AAPG Annual Convention and Exhibition, Pittsburgh, PA, USA, 19-22 May 2013. Search and Discovery Article \#10572.

120. Taylor, G.H.; Teichmüler, M.; Davis, A.; Diessel, C.F.K.; Littke, R.; Robert, P. Organic Petrology; Gebrüder Borntraeger: Berlin, Germany; Stuttgart, Germany, 1998.

121. Burtner, R.L.; Warner, M.A. Relationship between illite/smectite diagenesis and hydrocarbon generation in Lower Cretaceous Mowry and Skull Creek Shales of the Northern Rocky Mountain area. Clays Clay Miner. 1986, 34, 390-402. [CrossRef]

122. Velde, B.; Espitalié, J. Comparison of kerogen maturation and illite/smectite composition in diagenesis. J. Pet. Geol. 1989, 12, 103-110. [CrossRef]

123. Carvajal-Ortiz, H.; Gentzis, T. Geochemical screening of source rocks and reservoirs: The importance of using the proper analytical program. Int. J. Coal Geol. 2018, 190, 56-69. [CrossRef]

(C) 2020 by the authors. Licensee MDPI, Basel, Switzerland. This article is an open access article distributed under the terms and conditions of the Creative Commons Attribution (CC BY) license (http://creativecommons.org/licenses/by/4.0/). 